\title{
COX-2-Derived Prostaglandin E2 Produced by Pyramidal Neurons Contributes to Neurovascular Coupling in the Rodent Cerebral Cortex
}

\author{
Alexandre Lacroix, ${ }^{1,2,3 *}$ Xavier Toussay, ${ }^{1,2,3,4 \star}$ Eitan Anenberg, ${ }^{5}$ Clotilde Lecrux,${ }^{4}$ Nerea Ferreirós, ${ }^{6}$ \\ Anastassios Karagiannis, ${ }^{1,2,3}$ Fabrice Plaisier, ${ }^{1,2,3}$ Patrick Chausson, ${ }^{1,2,3}$ Frédéric Jarlier, ${ }^{1,2,3}$ Sean A. Burgess, ${ }^{7}$ \\ Elizabeth M. C. Hillman, ${ }^{7}$ Irmgard Tegeder, ${ }^{6}$ Timothy H. Murphy, ${ }^{5}$ Edith Hamel, ${ }^{4}$ and Bruno Cauli ${ }^{1,2,3}$ \\ ${ }^{1}$ Sorbonne Universités, UPMC Université Paris 06, Institut de Biologie Paris-Seine (IBPS), UM 119, Neuroscience Paris Seine, F-75005, Paris, France, \\ ${ }^{2}$ CNRS, UMR 8246, Neuroscience Paris Seine, F-75005, Paris, France, ${ }^{3}$ INSERM, UMR-S 1130, Neuroscience Paris Seine, F-75005, Paris, France, ${ }^{4}$ Laboratory \\ of Cerebrovascular Research, Montreal Neurological Institute, McGill University, Montréal, Québec H3A 2B4, Canada, ${ }^{5}$ Department of Psychiatry, \\ University of British Columbia, Vancouver, British Columbia V6T 1Z3, Canada, ${ }^{6}$ Department of Clinical Pharmacology, University-Hospital Frankfurt, \\ 60590 Frankfurt am Main, Germany, and 7 Department of Biomedical Engineering, Columbia University, New York, New York 10027
}

Vasodilatory prostaglandins play a key role in neurovascular coupling (NVC), the tight link between neuronal activity and local cerebral blood flow, but their precise identity, cellular origin and the receptors involved remain unclear. Here we show in rats that NMDA-induced vasodilation and hemodynamic responses evoked by whisker stimulation involve cyclooxygenase-2 (COX-2) activity and activation of the prostaglandin E2 $\left(\mathrm{PgE}_{2}\right)$ receptors EP2 and EP4. Using liquid chromatography-electrospray ionization-tandem mass spectrometry, we demonstrate that $\mathrm{PgE}_{2}$ is released by NMDA in cortical slices. The characterization of $\mathrm{PgE}_{2}$ producing cells by immunohistochemistry and single-cell reverse transcriptase-PCR revealed that pyramidal cells and not astrocytes are the main cell type equipped for $\mathrm{PgE}_{2}$ synthesis, one third expressing COX-2 systematically associated with a $\mathrm{PgE}_{2}$ synthase. Consistent with their central role in NVC, in vivo optogenetic stimulation of pyramidal cells evoked COX-2-dependent hyperemic responses in mice. These observations identify PgE $\mathrm{E}_{2}$ as the main prostaglandin mediating sensory-evoked NVC, pyramidal cells as their principal source and vasodilatory EP2 and EP4 receptors as their targets.

Key words: astrocytes; cerebral cortex; cyclooxygenase-2; interneurons; pyramidal cells

\section{Significance Statement}

Brain function critically depends on a permanent spatiotemporal match between neuronal activity and blood supply, known as NVC. In the cerebral cortex, prostaglandins are major contributors to NVC. However, their biochemical identity remains elusive and their cellular origins are still under debate. Although astrocytes can induce vasodilations through the release of prostaglandins, the recruitment of this pathway during sensory stimulation is questioned. Using multidisciplinary approaches from singlecell reverse transcriptase-PCR, mass spectrometry, to ex vivo and in vivo pharmacology and optogenetics, we provide compelling evidence identifying $\mathrm{PgE}_{2}$ as the main prostaglandin in $\mathrm{NVC}$, pyramidal neurons as their main cellular source and the vasodilatory EP2 and EP4 receptors as their main targets. These original findings will certainly change the current view of NVC.

\section{Introduction}

Neurovascular coupling (NVC), the tight link between neuronal activity and local cerebral blood flow, is essential for normal brain

Received Feb. 17, 2015; revised June 11, 2015; accepted June 30, 2015.

Author contributions: I.T., T.H.M., E.H., and B.C. designed research; A.L., X.T., E.A., C.L., N.F., A.K., F.P., P.C., I.T., and B.C. performed research; F.J., S.A.B., and E.M.C.H. contributed unpublished reagents/analytic tools; A.L., X.T., E.A., C.L., N.F., I.T., and B.C. analyzed data; X.T., E.A., C.L., I.T., T.H.M., E.H., and B.C. wrote the paper.

This work was supported by grants from the Human Frontier Science Program (RGY0070/2007; B.C. and E.M.C.H.), the Agence Nationale pour la Recherche (ANR 2011 MALZ 003 01; B.C.) "IHU Institut de Neurosciences Translationelles de Paris," (ANR-10-IAIHU-06; B.C.), the Fondation pour la Recherche sur le Cerveau / Rotary Club de function. It is also the physiological basis of functional brain imaging techniques, such as positron emission tomography and functional magnetic resonance imaging that are widely used to map neuronal activity using hemodynamic signals (Fox et al., 1988; Logothetis et al., 2001; Iadecola, 2004; Lauritzen, 2005). In several pathologies including Alzheimer's disease and stroke,

France (AOE-7 "Espoir en tête 2012"; B.C.), the Canadian Institutes of Health Research (CIHR, MOP-84209 to E.H. and MOP-12675 to T.H.M.), the Heart and Stroke Foundation of (anada (E.H. and T.H.M.), and by the Heart and Stroke Foundation of British Columbia and Yukon (T.H.M.) or Québec (E.H.), and T.H.M. and B.C. were supported by a joint 
NVC is altered by dysfunction in the neuronal, astroglial, and/or vascular compartments of the neurovascular unit (Iadecola, 2004; Zlokovic, 2011).

Despite this physiopathological importance the cellular and molecular mechanisms of NVC remain elusive. In the neocortex they involve various messengers (Attwell et al., 2010; Cauli and Hamel, 2010; Leithner et al., 2010; Liu et al., 2012). In rodents, vasodilatory prostaglandins play a key role in NVC accounting for approximately one-half of the hyperemic response to sensory stimuli (Niwa et al., 2000; Bakalova et al., 2002; Stefanovic et al., 2006; Lecrux et al., 2011). Prostaglandins are arachidonic acid derivatives produced by the sequential action of rate-limiting cyclooxygenases (COXs) and terminal synthesizing enzymes specifying their nature (Funk, 2001). Presumably because of the lack of selective inhibitors for terminal enzymes, most studies relied only on inhibiting COX-1 and/or COX-2 activity (Niwa et al., 2000, 2001; Bakalova et al., 2002; Zonta et al., 2003; Stefanovic et al., 2006; Takano et al., 2006; Gordon et al., 2008; Lecrux et al., 2011), hence lacking determination of the prostaglandin subspecies relevant for NVC.

In the cerebral cortex prostaglandin $\mathrm{E} 2\left(\mathrm{PgE}_{2}\right)$ and prostacyclin $\left(\mathrm{PgI}_{2}\right)$ are the main prostaglandins relaxing vascular smooth muscle cells and pericytes through activation of EP2, EP4, or IP receptors (Davis et al., 2004; Maubach et al., 2009; Myren et al., 2010, 2011; Woodward et al., 2011; Hall et al., 2014). Although antagonism of these receptors provides a means to identify the NVC prostaglandins, their use is still poorly documented (Hall et al., 2014) and has been limited by the confounding constrictive effect of the $\mathrm{PgE}_{2}$ receptor EP1 (Dabertrand et al., 2013).

The cellular sources of the NVC prostaglandins are also uncertain since different synthesizing enzymes are expressed in various cell types including neurons, astrocytes, microglia, and endothelial cells (Yamagata et al., 1993; Breder et al., 1995; Kaufmann et al., 1996; Mehl et al., 1999; Vazquez-Tello et al., 2004; Wang et al., 2005; Cahoy et al., 2008; Anrather et al., 2011; Lecrux et al., 2011).

We addressed these issues using ex vivo and in vivo approaches, and found that COX-2 and the $\mathrm{PgE}_{2}$ receptors $\mathrm{EP} 2$ and $\mathrm{EP} 4$ are essential contributors of NVC responses in the cerebral cortex. Consistently we demonstrate the $\mathrm{PgE}_{2}$ release ex vivo by means of liquid chromatography-electrospray ionization-tandem mass spectrometry (LC-ESI-MS/MS). Using immunocytochemistry and single-cell reverse transcriptase-PCR (scRT-PCR), we established that pyramidal cells are the major cell type equipped for COX-2-derived $\mathrm{PgE}_{2}$ synthesis. We further demonstrated their central role by concurrent in vivo optogenetic photostimulation of pyramidal cells and pharmacological manipulations of the NVC response. Our findings identify pyramidal cells and $\mathrm{PgE}_{2}$, respectively, as the major source and key vasoactive messenger of NVC responses to sensory stimulation.

\footnotetext{
UPMC and UBC collaborative grant funded by Djavad Mowafaghian Centre for Brain Health; part of this work was coordinated by CEA/MIRCen/IB2M and supported by the association France Alzheimer (ASTROinAD; B.C.); I.T. was supported by the Deutsche Forschungsgemeinschaft (CRC1039 A3) and A.K. was supported by a Fondation pour la Recherche Médicale fellowship (FDT20100920106). The funders had no role in study design, data collection and analysis, decision to publish, or preparation of the paper. We thank Alexandre Mourot and Jérémie Naudé for their help and assistance, Eleni Tzavara and Victor Gorgievski for providing the $\$ 100 \beta$ antibody, Monara Angelim and Pascal Legendre for providing the Iba-1 antibody, and the Cell Imaging and the animal facilities of the IBPS.

The authors declare no competing financial interest.

${ }^{*}$ A.L. and X.T. equally contributed to this work.

Correspondence should be addressed to Dr Bruno Cauli, Neuroscience Paris Seine CNRS UMR 8246, INSERM UMR-S 1130, UPMC UM 119, 9 Quai Street, Bernard, 75005 Paris, France. E-mail: bruno.cauli@upmc.fr.

DOI:10.1523/JNEUROSCI.0651-15.2015

Copyright $\odot 2015$ the authors $\quad 0270-6474 / 15 / 3511792-20 \$ 15.00 / 0$
}

\section{Materials and Methods}

Animals. Wistar rats (postnatal days $17.0 \pm 0.1$; Janvier) were used for patch-clamp recordings, vascular reactivity and measurement of prostanoids in acute slices. Adult Wistar or Sprague-Dawley rats (250-300 g) were respectively used for immunostaining $(n=7)$ or whisker-induced NVC experiments $(n=15)$. The Jackson Laboratory Line B6;129P$E m \times 1^{\text {tmlJlr }} / \mathrm{J}$ (Gorski et al., 2002) mice were crossed with B6;129SGt(ROSA)26Sor ${ }^{\left.\text {tm32.1(CAG-COP4 }{ }^{*} H 134 R / E Y F P\right) H z e} / \mathrm{J}$ mice (Madisen et al., 2012). Five male and female 2 - to 4 -month-old animals from the resultant strain weighing 20-30 g were used for optogenetic experiments. B6.Cg-Tg(Thyl-YFPH) ${ }^{2 \mathrm{Jr} / \mathrm{J}}$ mice (Feng et al., 2000) of the same age and weight were used for controls $(n=4)$. All animals were housed in a temperature-controlled $\left(21-25^{\circ} \mathrm{C}\right)$ room under daylight conditions and were given water ad libitum. A maximum of five mice or three rats are housed per cage and single animal housing was avoided. All experiments were performed in accordance with the EU Council Directive 86-609, the British Columbia Animal Care Committee and animal and Ethics committee of the Montreal Neurological Institute in accordance with Canadian Council for Animal Care guidelines.

Slice preparation. After decapitation brains were quickly removed and placed into cold $\left(\sim 4^{\circ} \mathrm{C}\right)$ oxygenated artificial CSF (aCSF) containing the following (in mM): $126 \mathrm{NaCl}, 2.5 \mathrm{KCl}, 1.25 \mathrm{NaH}_{2} \mathrm{PO}_{4}, 2 \mathrm{CaCl}_{2}, 1 \mathrm{MgCl}_{2}$, $26 \mathrm{NaHCO}_{3}, 10$ glucose, 15 sucrose, and 1 kynurenic acid (SigmaAldrich). For patch-clamp recordings and vascular reactivity rat coronal slices (300 $\mu \mathrm{m}$ thick) containing the barrel cortex were cut with a vibratome (VT1000S; Leica) and allowed to recover at room temperature for at least $1 \mathrm{~h}$ in aCSF saturated with $\mathrm{O}_{2} / \mathrm{CO}_{2}(95 \% / 5 \%)$ as previously described (Karagiannis et al., 2009). Slices were then transferred to a submerged recording chamber and perfused with oxygenated aCSF lacking kynurenic acid. Blood vessels and cells were first visualized in the slice under infrared (IR) illumination, using $60 \times($ LUMPlan FL/IR 60×/0.90 $\mathrm{W}$ ) or $40 \times($ LUMPlan FL N $40 \times / 0.80 \mathrm{~W}$ ) objectives attached to BX51WI (Olympus) or SliceScope (Scientifica) microscope equipped with Dodt gradient contrast optics (DGC; Luigs and Neumann; Dodt and Zieglgansberger, 1998) and collimated light emitting device (LED; $780 \mathrm{~nm}$, ThorLabs) as transmitted light sources. For prostaglandins and thromboxane analysis, parasagittal slices ( $400 \mu \mathrm{m}$ thick) were microdissected to isolate the sensorimotor cortex and the underlying white matter.

Vascular reactivity. Diving arterioles in layers I-III were selected under IR-DGC videomicroscopy on the basis of their well defined luminal diameter $(10-30 \mu \mathrm{m})$, their length remaining in the focal plane for at least $50 \mu \mathrm{m}$ (Cauli et al., 2004; Rancillac et al., 2006) and of the thickness of their wall ( $4.6 \pm 0.2 \mu \mathrm{m}, n=89$ arterioles; Table 1$)$ indicative of the presence of smooth muscle cells (Girouard et al., 2010). A resting period of at least $30 \mathrm{~min}$ (Lovick et al., 1999; Zonta et al., 2003) was observed after slice transfer. To limit the temperature-dependent toxicity of NMDA in slices (Andrew et al., 1996) images were acquired at room temperature every $10 \mathrm{~s}$ using a digital CCD camera (CoolSnap HQ2, Roper Scientific, or QIClick, QImaging) and Imaging Workbench 6.0.25 (INDEC BioSystems) or Image Pro Plus 6.3.1 (MediaCybernetics) software. The focal plane was maintained constantly on-line using parenchymal cells as anatomical landmarks. To compensate for potential $x-y$ drifts all images were realigned off-line using the "StackReg" plug-in (Thévenaz et al., 1998) of ImageJ 1.48 software. Luminal diameter was measured on registered images using custom analysis software developed in MATLAB (MathWorks). To ovoid potential drawbacks due to blood vessels instability, only arterioles exhibiting a stable luminal diameter were further taken into account. Arterioles were considered stable if the relative SD (RSD) of their luminal diameter during an initial baseline period of 5 min was $<5 \%$. Because arterioles have a limited myogenic tone in brain slices (Fergus and Lee, 1997; Lovick et al., 1999; Cauli et al., 2004; Rancillac et al., 2006; Mishra et al., 2014), blood vessels were preconstricted by superfusing the thromboxane A2 agonist, 9,11-dideoxy11a,9a-epoxymethanoprostaglandin F2 $\alpha$ (U46619; 50-75 nм). As the degree of vasoconstriction has been reported to influence the amplitude and polarity of vascular responses (Blanco et al., 2008), only arterioles developing a similar and stable vasoconstriction $(-40.6 \pm 1.5 \%$ of initial diameter, $\mathrm{RSD}<10 \%, n=89$ arterioles; Table 1; Movie 1) within the 40 
Table 1. Morphological and physiological properties of diving arterioles

\begin{tabular}{|c|c|c|c|c|c|c|c|c|}
\hline & $\begin{array}{l}\text { Ctrl } \\
(n=16)\end{array}$ & $\begin{array}{l}\text { Indo } \\
(n=6)\end{array}$ & $\begin{array}{l}\mathrm{SC} 560 \\
(n=12)\end{array}$ & $\begin{array}{l}\text { NS } 398 \\
(n=10)\end{array}$ & $\begin{array}{l}\text { AH } 6809 \\
(n=14)\end{array}$ & $\begin{array}{l}\mathrm{L} 161-982 \\
(n=11)\end{array}$ & $\begin{array}{l}\text { CAY } 10441 \\
(n=12)\end{array}$ & $\begin{array}{l}\text { TTX } \\
(n=8)\end{array}$ \\
\hline Resting luminal diameter, $\mu \mathrm{m}$ & $17.3 \pm 1.9$ & $\begin{array}{l}14.0 \pm 2.5 \\
U_{(16,6)}=36 \\
p=0.407007\end{array}$ & $\begin{array}{l}19.3 \pm 2.2 \\
U_{(16,12)}=78 \\
p=0.42275\end{array}$ & $\begin{array}{l}16.1 \pm 1.2 \\
U_{(16,10)}=80 \\
p=1\end{array}$ & $\begin{array}{l}14.9 \pm 1.4 \\
U_{(16,14)}=95 \\
p=0.49841\end{array}$ & $\begin{array}{l}16.9 \pm 2.4 \\
U_{(16,11)}=79 \\
p=0.680026\end{array}$ & $\begin{array}{l}16.6 \pm 1.5 \\
U_{(16,12)}=93 \\
p=0.909139\end{array}$ & $\begin{array}{l}16.3 \pm 2.2 \\
U_{(16,8)}=61 \\
p=0.880976\end{array}$ \\
\hline Wall thickness, $\mu \mathrm{m}$ & $4.9 \pm 0.4$ & $\begin{array}{c}4.6 \pm 0.5 \\
U_{(16,6)}=40 \\
p=0.590031\end{array}$ & $\begin{array}{c}4.2 \pm 0.4 \\
U_{(16,12)}=79 \\
p=0.449918\end{array}$ & $\begin{array}{c}4.7 \pm 0.4 \\
U_{(16,10)}=75.5 \\
p=0.815935\end{array}$ & $\begin{array}{c}4.9 \pm 0.4 \\
U_{(16,14)}=110 \\
p=0.951039\end{array}$ & $\begin{array}{c}5.2 \pm 0.5 \\
U_{(16,11)}=76 \\
p=0.576537\end{array}$ & $\begin{array}{c}4.2 \pm 0.4 \\
U_{(16,12)}=83 \\
p=0.567585\end{array}$ & $\begin{array}{c}3.9 \pm 0.6 \\
U_{(16,8)}=37 \\
p=0.105638\end{array}$ \\
\hline Resting stability, \% & $1.2 \pm 0.2$ & $\begin{array}{c}1.6 \pm 0.2 \\
U_{(16,6)}=25 \\
p=0.098026\end{array}$ & $\begin{array}{c}1.4 \pm 0.2 \\
U_{(16,12)}=73 \\
p=0.301529\end{array}$ & $\begin{array}{c}1.5 \pm 0.2 \\
U_{(16,10)}=57.5 \\
p=0.240562\end{array}$ & $\begin{array}{c}1.4 \pm 0.2 \\
U_{(16,14)}=93 \\
p=0.447547\end{array}$ & $\begin{array}{c}1.7 \pm 0.3 \\
U_{(16,11)}=61 \\
p=0.194506\end{array}$ & $\begin{array}{c}1.4 \pm 0.1 \\
U_{(16,12)}=72 \\
p=0.28029\end{array}$ & $\begin{array}{c}1.3 \pm 0.2 \\
U_{(16,8)}=49 \\
p=0.382604\end{array}$ \\
\hline Constriction level, $\%$ & $46.5 \pm 3.2$ & $\begin{array}{l}46.0 \pm 6.5 \\
U_{(16,6)}=45 \\
p=0.857733\end{array}$ & $\begin{array}{l}45.1 \pm 4.9 \\
U_{(16,12)}=93.5 \\
p=0.909139\end{array}$ & $\begin{array}{l}39.4 \pm 5.0 \\
U_{(16,10)}=52 \\
p=0.149647\end{array}$ & $\begin{array}{l}37.5 \pm 3.5 \\
U_{(16,14)}=69 \\
p=0.077067\end{array}$ & $\begin{array}{l}37.2 \pm 4.5 \\
U_{(16,11)}=58.5 \\
p=0.14767\end{array}$ & $\begin{array}{l}37.2 \pm 3.5 \\
U_{(16,12)}=57 \\
p=0.07354\end{array}$ & $\begin{array}{l}35.3 \pm 4.8 \\
U_{(16,8)}=37.5 \\
p=0.105638\end{array}$ \\
\hline Constriction stability, \% & $3.4 \pm 0.6$ & $\begin{array}{c}3.9 \pm 0.7 \\
U_{(16,6)}=35 \\
p=0.366773\end{array}$ & $\begin{array}{c}3.2 \pm 0.6 \\
U_{(16,12)}=92.5 \\
p=0.873052\end{array}$ & $\begin{array}{c}3.1 \pm 0.4 \\
U_{(16,10)}=74 \\
p=0.775995\end{array}$ & $\begin{array}{c}3.1 \pm 0.5 \\
U_{(16,14)}=105 \\
p=0.790107\end{array}$ & $\begin{array}{c}3.1 \pm 0.6 \\
U_{(16,11)}=85 \\
p=0.903538\end{array}$ & $\begin{array}{c}2.6 \pm 0.4 \\
U_{(16,12)}=82 \\
p=0.536889\end{array}$ & $\begin{array}{c}2.4 \pm 0.2 \\
U_{(16,8)}=50 \\
p=0.41665\end{array}$ \\
\hline & & & \multicolumn{6}{|c|}{$\pi$} \\
\hline
\end{tabular}

Ctrl, Control; Indo, indomethacin;SC 560, COX-1 inhibitor; NS398, COX-2 inhibitor; AH 6809, EP1/2 receptor antagonist; L 161-982, EP4 receptor antagonist; CAY 10441, IP receptor antagonist; TTX, tetrodotoxin; n, number of diving arterioles. Values are mean \pm SEM Mann-Whitney $U$ test and corresponding exact $p$ values. n.S., not statistically significant from control condition with Bonferroni correction for multiple comparisons.

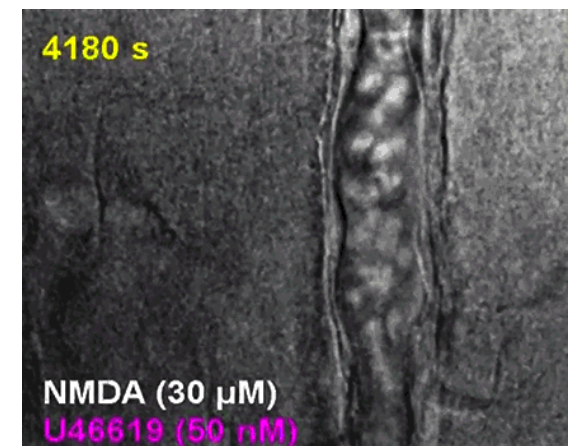

Movie 1. NMDA induced vasodilation. Diving cortical arteriole visualized in a slice by IR-DGC was preconstricted with U46619 (50 nM, 310-6000 s). Bath application of $30 \mu \mathrm{M} \mathrm{NMDA}$ (3910 - 4200 s) reversibly dilated blood vessel. For more details, see Figure 1.

min following U46619 application were included in the analysis. NMDA $(30 \mu \mathrm{M})$ was bath-applied for $5 \mathrm{~min}$ after $60 \mathrm{~min}$ of U46619 superfusion (Movie 1). COX-1/2 inhibitors and prostaglandin receptor antagonists were applied $30 \mathrm{~min}$ before NMDA application and throughout all the duration of the experiment. Tetrodotoxin (TTX) was applied 15 min before NMDA application. Only one arteriole was monitored per slice. Dilatory responses are expressed as changes relatively to the preconstricted state. The magnitude (Bakalova et al., 2002) of vasodilations was defined as the integral of diameter changes measured for a period of $1000 \mathrm{~s}$ following the onset of vasodilation.

Analysis of prostaglandins and thromboxane: collection of supernatants and slices. Four acute slices and a control slice were placed in two wells of a 12-well plate filled with $1 \mathrm{ml}$ of oxygenated aCSF containing $50 \mathrm{~nm}$ $\mathrm{U} 46619$ and a mixture of $\mathrm{O}_{2} / \mathrm{CO}_{2}(95 \% / 5 \%)$ was continuously delivered. After an equilibration period of $30 \mathrm{~min}, 100 \mu \mathrm{l}$ of supernatant were collected and rapidly frozen in dry ice $(t=-30 \mathrm{~min})$. One-hundred microliters of SC 560, NS 398 or their vehicle (DMSO 0.02\%) were then added to the medium. After $30 \mathrm{~min}$ of incubation $100 \mu \mathrm{l}$ of supernatant were collected, rapidly frozen in dry ice $(t=0 \mathrm{~min})$, and replaced by a solution supplemented with NMDA or its vehicle (water). After 2 and 5 min of incubation 100 and $\sim 900 \mu \mathrm{l}$ were, respectively, collected, frozen, and replaced by $1 \mathrm{ml}$ of aCSF containing COX-inhibitor or its vehicle but lacking NMDA. One-hundred microliters of supernatant were collected $5 \mathrm{~min}$ and $15 \mathrm{~min}$ after NMDA washout $(t=10$ and $20 \mathrm{~min}$, respec- tively). After $25 \mathrm{~min}$, all of the remaining supernatant (i.e., $\sim 800 \mu \mathrm{l}$ ) was collected and frozen as well as the four slices. Viability of slices after treatment was evaluated by ensuring that the control slice displayed numerous healthy-looking cells when observed under IR-DGC illumination.

Analysis of prostaglandins and thromboxane: equipment. Lipid analysis was performed using LC-ESI-MS/MS. The LC-MS/MS system consisted of a hybrid triple quadrupole-ion trap QTrap 5500 mass spectrometer (AB Sciex) equipped with a Turbo-V-source operating in negative ESI mode, an Agilent 1200 binary HPLC pump, column oven $\left(40^{\circ} \mathrm{C}\right)$ and degasser (Agilent) and an HTC Pal autosampler (Chromtech) with a cooling stack which kept the samples at $4^{\circ} \mathrm{C}$. High-purity nitrogen for the mass spectrometer was produced by a NGM 22-LC/MS nitrogen generator (Cmc Instruments).

Analysis of prostaglandins and thromboxane: extraction and mass spectrometry. Analysis of prostaglandin content was performed as previously described (Schmitz et al., 2014). The homogenized tissue pieces and the slice supernatants were extracted by two rounds of liquid-liquid extraction with ethylacetate $(600 \mu \mathrm{l})$. The samples were spiked before extraction with the internal standard mixture, $100 \mu \mathrm{l}$ of $0.15 \mathrm{M}$ EDTA and $10 \mu \mathrm{l}$ BHT ( $2 \mathrm{mg} / \mathrm{ml}$ in methanol) to prevent oxidation of analytes. After vortexing and centrifugation for $3 \mathrm{~min}$ at $17,000 \times \mathrm{g}$, the organic fractions were combined and evaporated at a temperature of $45^{\circ} \mathrm{C}$ under a gentle stream of nitrogen.

LC-MS/MS conditions. For the chromatographic separation a Synergi Hydro-RP column and precolumn were used $(150 \times 2 \mathrm{~mm}$ I.D., $4 \mu \mathrm{m}$ particle size and $80 \AA$ pore size from Phenomenex). A linear gradient was used at a flow rate of $300 \mu \mathrm{l} / \mathrm{min}$. The mobile phase $A$ was water/formic acid (100:0.0025, v/v, pH 4.0) and mobile phase B acetonitrile/formic acid (100: $0.0025, \mathrm{v} / \mathrm{v})$. The sample solvent was acetonitrile/water/formic acid (20:80: $0.0025, \mathrm{v} / \mathrm{v}, \mathrm{pH} 4.0)$. The total run time was $16 \mathrm{~min}$ and injection volume 45 $\mu$ l. Retention times of 6-keto- $\mathrm{PgF}_{1 \alpha}, \mathrm{TXB}_{2}, \mathrm{PgF}_{2 \alpha}, \mathrm{PgE}_{2}$, and $\mathrm{PgD}_{2}$ were 7.4, 8.0, 8.2, 8.7, and $9.2 \mathrm{~min}$, respectively.

The mass spectrometer was operated in the negative ion mode with an electrospray voltage of $-4500 \mathrm{~V}$ at $450^{\circ} \mathrm{C}$. Multiple reaction monitoring was used for quantification. The mass transitions used are $\mathrm{m} / \mathrm{z} 351.1$ $\rightarrow \mathrm{m} / \mathrm{z} 315.0$ for $\mathrm{PgE}_{2}$ and $\mathrm{PgD}_{2}, \mathrm{~m} / \mathrm{z} 353.1 \rightarrow \mathrm{m} / \mathrm{z} 309.2$ for $\mathrm{PgF} 2 \alpha, \mathrm{m} / \mathrm{z}$ $369.1 \rightarrow \mathrm{m} / \mathrm{z} 163.0$ for 6-keto-PgF1 $\alpha, \mathrm{m} / \mathrm{z} 369.1 \rightarrow \mathrm{m} / \mathrm{z} 169.1$ for TXB2, $\mathrm{m} / \mathrm{z} 355.1 \rightarrow \mathrm{m} / \mathrm{z} 275.1$ for $[2 \mathrm{H} 4]-\mathrm{PgE}_{2}$ and $[2 \mathrm{H} 4]-\mathrm{PgD}_{2}, \mathrm{~m} / \mathrm{z} 357.1$ $\rightarrow \mathrm{m} / \mathrm{z} 313.2$ for [2H4]- $\mathrm{PgF}_{2 \alpha}$, m/z 373.2 $\rightarrow \mathrm{m} / \mathrm{z} 167.1$ for [2H4]-6-keto$\mathrm{PgF}_{1 \alpha}$ and $\mathrm{m} / \mathrm{z} 373.1 \rightarrow \mathrm{m} / \mathrm{z} 173.1$ for $[2 \mathrm{H} 4]-\mathrm{TXB}_{2}$ all with a dwell time of $50 \mathrm{~ms}$. All quadrupoles were working at unit resolution. 
Quantification. Concentrations of the calibration standards, quality controls, and unknowns were evaluated by Analyst software (v1.5; B Sciex). Ratios of peak areas of the lipid and the respective internal standard ( $y$-axis) were plotted against concentration ( $x$-axis) and calibration curves for each lipid were calculated by least-square regression analysis with $1 /$ concentration $^{2}$ weighting. Variations in accuracy and intraday and interday precision ( $n=6$ for each concentration, respectively) were $<15 \%$ over the respective ranges of calibration $(0.02-250 \mathrm{ng} / \mathrm{ml}$ for $\mathrm{PgE}_{2}, \mathrm{PgD}_{2}$ and 6keto- $\mathrm{PgF}_{1 \alpha} ; 0.075-250$ for $\mathrm{TXB}_{2}$ and $0.08-1000$ for $\left.\mathrm{PgF}_{2 \alpha}\right)$.

Astrocytes vital staining. Slices were vitally stained by a 20 min superfusion of aCSF containing $1 \mu \mathrm{M}$ sulforhodamine 101 (SR101, SigmaAldrich) or $2 \mu \mathrm{M}$ TexasRed hydrazide (TxRed; Invitrogen) and rinsed for at least $10 \mathrm{~min}$ (Lecrux et al., 2011). SR101 and TxRed were excited at 535 nm with a LED (CoolLED, Precise Excite) and red fluorescence was collected using a Triple-beamsplitter 395/495/610 (FF395/495/610Di01-25x36, Semrock) and a Tripleband emission filter 425/527/685 (FF01-425/527/685-25, Semrock). IR-DGC and fluorescent Images were captured with a digital CCD camera (CoolSnap HQ2) and Imaging Workbench 6.0.25 software.

Whole-cell recordings. Patch pipettes $(5.5 \pm 0.1 \mathrm{M} \Omega)$ pulled from borosilicate glass were filled with $8 \mu \mathrm{l}$ of RNase free internal solution containing the following in (mM): $144 \mathrm{~K}$-gluconate, $3 \mathrm{MgCl}_{2}, 0.5 \mathrm{EGTA}$, 10 HEPES, pH 7.2 (285/295 mOsm). Whole-cell recordings were performed at $27.0 \pm 0.5^{\circ} \mathrm{C}$ using a patch-clamp amplifier (Axopatch 200B, MDS). Data were filtered at $5-10 \mathrm{kHz}$ and digitized at $50 \mathrm{kHz}$ using an acquisition board (Digidata 1440, MDS) attached to a personal computer running pCLAMP 10.2 software package (MDS).

Electrophysiological properties were determined in voltage-clamp mode for astrocytes (Houades et al., 2008; Lecrux et al., 2011) and current-clamp mode for neurons (Karagiannis et al., 2009). Membrane potential values were not corrected for liquid junction potential. Input resistance of astrocytes was determined by plotting a voltage/current curve of the current response at steady state. This resistance was corrected for series resistance determined by plotting a voltage/current curve of the capacitive transients (Houades et al., 2008). Resting membrane potential of astrocytes was determined by calculating the intercept of the voltage/current curve with the $0 \mathrm{pA}$ value. Resting membrane potential of neurons was measured just after passing in whole-cell configuration. Only neurons with a resting membrane potential more negative than $-51 \mathrm{mV}$ were analyzed further. Thirty-two electrophysiological properties chosen to describe the electrophysiological diversity of cortical neurons (Ascoli et al., 2008) were determined as previously described (Karagiannis et al., 2009) using custom analysis software developed in MATLAB (MathWorks).

Morphological analysis of IR-DGC images. Arteriole wall thickness was measured manually using Image-Pro Analyzer 7.0.0.951 software (Media Cybernetics). Somatic features were measured from IR-DGC images of the recorded cells as previously described (Karagiannis et al., 2009). Briefly, the soma was manually delineated using Image-Pro Analyzer 7.0.0.951 software. Then, the length of major and minor axes, the perimeter, and the area were extracted. The soma elongation was calculated as the ratio between major and minor axes. Roundness was calculated according to:

$$
\frac{\text { perimeter }^{2}}{4 \pi \times \text { area }}
$$

A value close to 1 is indicative of round somata. Somata with no obvious process and displaying a roundness value lower than 1.5 was considered as round. Cells with a soma exhibiting two processes in opposite direction were defined as fusiform if their elongation was $>2$ (Cauli et al., 2000 ). If it was $<2$, cells were considered as ovoid. Cells whose soma had $>2$ processes were defined as irregular.

Cytoplasm harvest and scRT-PCR. At the end of the whole-cell recording lasting $<20 \mathrm{~min}$, the cytoplasmic content was aspirated in the recording pipette. The pipette's content was expelled into a test tube and RT was performed in a final volume of $10 \mu \mathrm{l}$, as described previously (Lambolez et al., 1992). Two scRT-PCR protocols were designed to probe simulta- neously for the expression of prostaglandin synthesizing enzymes and well established markers of cortical astrocytes (Houades et al., 2008) or neurons (Ascoli et al., 2008; Karagiannis et al., 2009). Prostaglandinsynthesizing enzymes included COX-1 and COX-2, the terminal $\mathrm{PgE}_{2}$ synthases (PGES); mPGES1, mPGES2, and cPGES, and PgI ${ }_{2}$ synthase (PGIS). Astrocytes markers included $S 100 \beta$ and glial fibrillary acidic protein (GFAP). Neuronal markers included the vesicular glutamate transporter, vGluT1, the two isoforms of glutamic acid decarboxylase (GAD65 and GAD67), the neuronal isoform of nitric oxide synthase (NOS-1), calbindin (CB), calretinin (CR), parvalbumin (PV), neuropeptide Y (NPY) or vasoactive intestinal polypeptide (VIP), somatostatin (SOM), and cholecystokinin (CCK). Two-steps amplification was performed essentially as described previously (Cauli et al., 1997) using the primer pairs listed in Table 2. Ten microliters of each individual PCR product were run on a $2 \%$ agarose gel stained with ethidium bromide using $\Phi$ X174 digested by HaeIII as a molecular weight marker.

Double-fluorescence labeling. Rats were deeply anesthetized with sodium pentobarbital (50 mg/kg, i.p.) and their brain were perfusion-fixed (500 $\mathrm{ml}$ of ice-cold $4 \%$ paraformaldehyde (PFA), in $0.1 \mathrm{M}$ phosphate buffer, $\mathrm{pH} 7.4)$, and postfixed by immersion in $4 \% \mathrm{PFA}\left(2 \mathrm{~h}, 4^{\circ} \mathrm{C}\right)$. Brains were then cut in $50-\mu \mathrm{m}$-thick coronal sections with a HM $650 \mathrm{~V}$ vibratome (Microm). Sections from three to four different rat brains were simultaneously incubated overnight with the primary antibodies against COX-2 and specific markers. Antibodies included goat anti-COX-2 (1: 2000; sc-1747, Santa Cruz Biotechnology; Damm et al., 2011), rabbit anti-ionized calcium-binding adapter molecule 1 (Iba-1, 1:1000, no. 019-19741, Wako Pure Chemical Industries; Lloyd-Burton and Roskams, 2012), rabbit anti-S100 $\beta$ (1:2000, no. 37, Swant; Horky et al., 2006), rabbit anti-Satb2 (1:1000, ab34735, Abcam; S. Lee et al., 2010). The respective immunoreactions were visualized with the following secondary antibodies: donkey-anti goat AlexaFluor 555 (1:400, A21432, Invitrogen), donkey-anti mouse AlexaFluor 488 (1:400, A21202, Invitrogen), and donkey-anti rabbit AlexaFluor 488 (1:400, A21206, Invitrogen). The vascular bed was labeled with biotinylated lycopersicon esculentum agglutinin (LEA; $10 \mu \mathrm{g} / \mathrm{ml}, \mathrm{B}-1175$, Vector Laboratories; Mazzetti et al., 2004) and revealed with AlexaFluor 488 streptavidin (1: 400, S-11223, Invitrogen). Sections were mounted with Vectashield (Vector Laboratories) on gelatin-coated slides for visualization. Images of immunostained material were acquired using a TCS SP5 confocal microscope with a $20 \times$ objective $(20 \times$ HC Plan APO IMM COR CS NA $0.7 /$ Oil) and LAS AF software (Leica Microsystems). Cell counting and image processing were performed using Image Pro Plus 4.1.0.0 and Image Pro Analyzer 7.0.0.951 (MediaCybernetics) respectively.

NVC to whisker stimulation using laser Doppler flowmetry (LDF). Rats were anesthetized (urethane, $1 \mathrm{~g} / \mathrm{ml}$, i.p.), cannulated in the femoral artery for blood gas and blood pressure measurements, and placed in a stereotaxic frame (David Kopf Instruments). Body temperature was maintained at $37^{\circ} \mathrm{C}$ using a rectal probe connected to a homeothermic blanket (Harvard apparatus). The posterior atlanto-occipital membrane was exposed for intracisternal injection $(3 \mu \mathrm{l}, 1 \mu \mathrm{l} / \mathrm{min})$ of vehicle and drugs using a $30 \mathrm{G}$ needle connected to a $10 \mu \mathrm{l}$ Hamilton syringe driven by a Harvard infusion pump, as previously described (Lecrux et al., 2011). All drugs effects were measured on whisker stimulation at $20 \mathrm{~min}$ after intracisternal injection. CAY 10441 and its vehicle slightly, but significantly, affected baseline blood flow. Left whiskers were trimmed, attached to a glass capillary connected to a Piezo actuator (Piezo Systems) placed in a Faraday cage and driven by an isolated pulse stimulator $(8 \mathrm{~Hz}$, A-M Systems, Model 2100) controlled by PowerLab (AD Instruments). Seven stimulation blocks ( $40 \mathrm{~s}$ baseline, $20 \mathrm{~s}$ stimulation) were given for each condition (control, vehicle, and drug) with only one drug being tested in each rat. The skull over the right barrel cortex was thinned to translucency for positioning of the laser-Doppler probe (wavelength: 785 $\mathrm{nm}, 0.58 \mathrm{~mm}$ diameter, $0.5 \mathrm{~mm}$ transmit/receive spacing, Transonic Systems). Following placement of the laser Doppler probe over the most responsive region of the barrel cortex, a tungsten microelectrode (FHC) was inserted using stereotaxic manipulators with an angle $\left(40^{\circ}\right)$ in the cortical depth $(1 \mathrm{~mm})$ as close as possible $( \pm 1.5 \mathrm{~mm})$ of the LDF probe for simultaneous local field potential (LFP) recordings and another microelectrode was positioned symmetrically in the corresponding ipsilat- 
Table 2. PCR primers

\begin{tabular}{|c|c|c|c|c|}
\hline Genes accession no. & First $P C R$ primers & Size, bp & Second PCR nested primers & Size, bp \\
\hline $\begin{array}{l}\text { GFAP } \\
\text { NM_017009 }\end{array}$ & $\begin{array}{l}\text { Sense, 454: AAGCTCCAAGATGAAACCAACCT } \\
\text { (Lambolez et al., 1992) } \\
\text { Antisense, 1066: (GATCTCGATGTCCAGGGC } \\
\text { (Lambolez et al., 1992) }\end{array}$ & 631 & $\begin{array}{l}\text { Sense, } 509 \text { ACAGACAGGAGGCGGATGAA } \\
\text { (Lecrux et al., 2011) } \\
\text { Antisense, 749 GGACCGATACCACTCTTCTGTTT } \\
\text { (Lecrux et al., 2011) }\end{array}$ & 263 \\
\hline $\begin{array}{l}\text { S100 } \beta \\
\text { NM_013191.1 }\end{array}$ & $\begin{array}{l}\text { Sense, 45: CCATCAGTATTCAGGGAGAGAGGG } \\
\text { (Lecrux et al., 2011) } \\
\text { Antisense, 191: GTCACACTCCCCATCCCCAT } \\
\text { (Lecrux et al., 2011) }\end{array}$ & 166 & $\begin{array}{l}\text { Sense, 58: GGGAGAGAGGGTGACAAGCA } \\
\text { (Lecrux et al., 2011) } \\
\text { Antisense, 170: TTCGTCCAGCGTCTCCATCA } \\
\text { (Lecrux et al., 2011) }\end{array}$ & 132 \\
\hline $\begin{array}{l}\text { vGluT1 } \\
\text { NM_053859.1 }\end{array}$ & $\begin{array}{l}\text { Sense, 361: GGCTCCTTTTTCTGGGGGTAC } \\
\text { (Gallopin et al., 2006) } \\
\text { Antisense, 600: CCAGCCGACTCCGTTCTAAG } \\
\text { (Gallopin et al., 2006) }\end{array}$ & 259 & $\begin{array}{l}\text { Sense, 373: TGGGGGTACATTGTCACTCAGA } \\
\text { (Gallopin et al., 2006) } \\
\text { Antisense, 553:ATGGCAAGCAGGGTATGTGAC } \\
\text { (Gallopin et al., 2006) }\end{array}$ & 201 \\
\hline $\begin{array}{l}\text { GAD65 } \\
\text { NM_012563.1 }\end{array}$ & $\begin{array}{l}\text { Sense, 713: TCTTTTCTCCTGGTGGTGCC } \\
\text { (Bochet et al., 1994) } \\
\text { Antisense, 1085: CCCCAAGCAGCATCCACAT } \\
\text { (Bochet et al., 1994) }\end{array}$ & 391 & $\begin{array}{l}\text { Sense, 743: TGTACGCCATGCTCATTGCC } \\
\text { (Gallopin et al., 2006) } \\
\text { Antisense, 1032: CAGCTACAGCCAAGAGAGGATCA } \\
\text { (Gallopin et al., 2006) }\end{array}$ & 312 \\
\hline $\begin{array}{l}\text { GAD67 } \\
\text { NM_017007.1 }\end{array}$ & $\begin{array}{l}\text { Sense, 529: TACGGGGTTCGCACAGGTC } \\
\text { (Cauli et al., 1997) } \\
\text { Antisense, 1109: CCCCAAGCAGCATCCACAT } \\
\text { (Cauli et al., 1997) }\end{array}$ & 599 & $\begin{array}{l}\text { Sense, 581: TGGATATCATTGGTTTAGCTGGC } \\
\text { (Gallopin et al., 2006) } \\
\text { Antisense, 1065: TCACATATGTCTGCAATCTCCTGG } \\
\text { (Gallopin et al., 2006) }\end{array}$ & 508 \\
\hline $\begin{array}{l}\text { NOS-1 } \\
\text { NM_052799.1 }\end{array}$ & $\begin{array}{l}\text { Sense, 2816: AACTGGGAGGGGAGAGGATTC } \\
\text { (Cauli et al., 2004) } \\
\text { Antisense, 3323: GGGTGGGAGGCGAGATTCAT } \\
\text { (Cauli et al., 2004) }\end{array}$ & 548 & $\begin{array}{l}\text { Sense, 2829: GAGGATTCTGAAGATGAGGGAGG } \\
\text { Antisense, 3323: CCTTCCAATTACTGATGACACCC }\end{array}$ & 517 \\
\hline $\begin{array}{l}\text { CB } \\
\text { NM_031984.2 }\end{array}$ & $\begin{array}{l}\text { Sense, 134: AGGCACGAAAGAAGGCTGGAT } \\
\text { (Cauli et al., 1997) } \\
\text { Antisense, 544: TCCCACACATTtTGATTCCCTG } \\
\text { (Cauli et al., 1997) }\end{array}$ & 432 & $\begin{array}{l}\text { Sense, 166: CCTGAGATGAAAACCTTTGTGG } \\
\text { (Gallopin et al., 2006) } \\
\text { Antisense, 392: CACGGTCTTGTTTGCTTTCTCTA } \\
\text { (Gallopin et al., 2006) }\end{array}$ & 249 \\
\hline $\begin{array}{l}\text { PV } \\
\text { NM_022499.2 }\end{array}$ & $\begin{array}{l}\text { Sense, 115: AAGAGTGCGGATGATGTGAAGA } \\
\text { (Cauli et al., 1997) } \\
\text { Antisense, 480: TTGTTTCTCCAGCATTTTCCAG } \\
\text { (Cauli et al., 1997) }\end{array}$ & 388 & $\begin{array}{l}\text { Sense, 151: CTGGACAAAGACAAAAGTGGCT } \\
\text { (Gallopin et al., 2006) } \\
\text { Antisense,376: AGAAGGGCTGAGATGGGGC } \\
\text { (Gallopin et al., 2006) }\end{array}$ & 244 \\
\hline $\begin{array}{l}\text { CR } \\
\text { NM_053988.1 }\end{array}$ & $\begin{array}{l}\text { Sense, 142: CTGGAGAAGGCAAGGAAAGGT } \\
\text { (Cauli et al., 1997) } \\
\text { Antisense, 429: AGGTTCATCATAGGGAGGGTTG } \\
\text { (Cauli et al., 1997) }\end{array}$ & 309 & $\begin{array}{l}\text { Sense, 157: AAAGGTTCTGGCATGATGTCC } \\
\text { (Gallopin et al., 2006) } \\
\text { Antisense, 401: TCAGGAGGTCGGACAGAAATC } \\
\text { (Gallopin et al., 2006) }\end{array}$ & 265 \\
\hline $\begin{array}{l}\text { NPY } \\
\text { NM_012614.1 }\end{array}$ & $\begin{array}{l}\text { Sense, -45: GCCCAGAGCAGAGCACCC } \\
\text { (Cauli et al., 1997) } \\
\text { Antisense, 292: CAAGTTTCATTTCCCATCACCA } \\
\text { (Cauli et al., 1997) }\end{array}$ & 359 & $\begin{array}{l}\text { Sense, - 21: CAGAGACCACAGCCCGCC } \\
\text { (Gallopin et al., 2006) } \\
\text { Antisense, 261: (TTCAAGCCTTGTTCTGGGG } \\
\text { (Gallopin et al., 2006) }\end{array}$ & 302 \\
\hline $\begin{array}{l}\text { VIP } \\
\text { NM_053991.1 }\end{array}$ & $\begin{array}{l}\text { Sense, 189: TGCCTTAGCGGAGAATGACA } \\
\text { (Cauli et al., 1997) } \\
\text { Antisense, 456: CCTCACTGCTCCTCTTCCCA } \\
\text { (Cauli et al., 1997) }\end{array}$ & 287 & $\begin{array}{l}\text { Sense, 208: ACGCCCTATTATGATGTGTCCAG } \\
\text { (Gallopin et al., 2006) } \\
\text { Antisense, 402: TTTGCTTTCTAAGGCGGGTG } \\
\text { (Gallopin et al., 2006) }\end{array}$ & 214 \\
\hline $\begin{array}{l}\text { SOM } \\
\text { NM_012659.1 }\end{array}$ & $\begin{array}{l}\text { Sense, 43: ATCGTCCTGGCTTTGGGC } \\
\text { (Cauli et al., 1997) } \\
\text { Antisense, 231: GCCTCATCTCGTCCTGCTCA } \\
\text { (Cauli et al., 1997) }\end{array}$ & 208 & $\begin{array}{l}\text { Sense, 75: GCCCTCGGACCCCAGACT } \\
\text { (Gallopin et al., 2006) } \\
\text { Antisense, 207: TGGGGCAAATCCTCAGGC } \\
\text { (Gallopin et al., 2006) }\end{array}$ & 150 \\
\hline $\begin{array}{l}\text { CCK } \\
\text { NM_012829.1 }\end{array}$ & $\begin{array}{l}\text { Sense, 177: CGCACTGCTAGCCCGATACA } \\
\text { (Cauli et al., 1997) } \\
\text { Antisense, 373: TTTCTCATTCCGCCTCCTCC } \\
\text { (Cauli et al., 1997) }\end{array}$ & 216 & $\begin{array}{l}\text { Sense, 192: ATACATCCAGCAGGTCCGCA } \\
\text { (Gallopin et al., 2006) } \\
\text { Antisense, 320: TGGGTATTCGTAGTCCTCAGCAC } \\
\text { (Gallopin et al., 2006) }\end{array}$ & 151 \\
\hline $\begin{array}{l}\text { COX-1 } \\
\text { NM_017043.1 }\end{array}$ & $\begin{array}{l}\text { Sense, 27: GTTTCCCCTGCTGCTGCTC } \\
\text { (Lecrux et al., 2011) } \\
\text { Antisense, 366: GGCTGGGGATAAGGTTGGAC } \\
\text { (Lecrux et al., 2011) }\end{array}$ & 359 & $\begin{array}{l}\text { Sense, 137: AGGGTGTCTGTGTCCGCTTC } \\
\text { (Lecrux et al., 2011) } \\
\text { Antisense, 301: GGCATTCACAAACTCCCAGAT } \\
\text { (Lecrux et al., 2011) }\end{array}$ & 185 \\
\hline $\begin{array}{l}\text { COX-2 } \\
\text { NM_017232.2 }\end{array}$ & $\begin{array}{l}\text { Sense, 199: CTGAAGCCCACCCCAAACAC } \\
\text { (Lecrux et al., 2011) } \\
\text { Antisense, 426: TGGGAGTTGGGCAGTCATCA } \\
\text { (Lecrux et al., 2011) }\end{array}$ & 247 & $\begin{array}{l}\text { Sense, 202: AAGCCCACCCCAAACACAGT } \\
\text { (Lecrux et al., 2011) } \\
\text { Antisense, 384: CTGGTGTAGTAGGAGAGGTTGGAG } \\
\text { (Lecrux et al., 2011) }\end{array}$ & 206 \\
\hline $\begin{array}{l}\text { mPGES1 } \\
\text { NM_021583.2 }\end{array}$ & $\begin{array}{l}\text { Sense, 9: CCTGGGTTTGGTGATGGAGAA } \\
\text { Antisense, 350: GGTTCATTTTGCCCAGGTAGG }\end{array}$ & 362 & $\begin{array}{l}\text { Sense, 36: GGTGCTCCCCGCCTTTCT } \\
\text { Antisense, 303: TGAGGACCACGAGGAAATGTATC }\end{array}$ & 290 \\
\hline $\begin{array}{l}\text { mPGES2 } \\
\text { NM } 001107832.1\end{array}$ & $\begin{array}{l}\text { Sense, 358: GACTTCCACTCCCTGCCCT } \\
\text { Antisense, 686: CTGCCGCCACTTCATCTCCT }\end{array}$ & 348 & $\begin{array}{l}\text { Sense, 381: GGTGGTAGAGGTGAATCCCG } \\
\text { Antisense, 652: TTTCCGCCATACATCTGCTG }\end{array}$ & 291 \\
\hline $\begin{array}{l}\text { CPGES } \\
\text { NM_001130989.1 }\end{array}$ & $\begin{array}{l}\text { Sense, - 18: GCCCTCTGCCCCGTTCAC } \\
\text { Antisense, 266: GCTTTGCCCTTTCCTTTGTTA }\end{array}$ & 305 & $\begin{array}{l}\text { Sense, 26: ACGACCGAAGGGACTATGTATT } \\
\text { Antisense, 191: CTGTCCGTTCTTTTATGCTTGG }\end{array}$ & 187 \\
\hline $\begin{array}{l}\text { PGIS } \\
\text { NM_031557.2 }\end{array}$ & $\begin{array}{l}\text { Sense, 1142: GTGACCGCCTTCTCCTCTTTC } \\
\text { Antisense, 1361: TCAGCAGCAGGACCACAAACT }\end{array}$ & 240 & $\begin{array}{l}\text { Sense, 1174: CCCCAGAAGGACCCAGAAATC } \\
\text { Antisense, 1342: ACTGTTTGATGCTGTTGATGGC }\end{array}$ & 190 \\
\hline
\end{tabular}


eral barrel cortex. Recordings of LFPs were performed through a 2-channel amplifier (A-M Systems, model 1800), a reference screw being placed on the dura over the frontal cortex. Electrophysiological data were filtered $(10-500 \mathrm{~Hz})$, amplified and acquired at $10 \mathrm{kHz}$ through a PowerLab (AD Instruments) and analyzed using script written in MATLAB (MathWorks). LDF data were extracted for every second using LabChart software (AD instruments), and whisker-evoked cerebral blood flow (CBF) changes over baseline for the seven stimulation blocks were averaged. LFPs on the contralateral and corresponding ipsilateral barrel cortex were averaged every $125 \mathrm{~ms}$ for each $20 \mathrm{~s}$ stimulation, and the LFP amplitude, defined as the difference between the maximal and minimal values, was averaged over the repeated blocks and normalized from control condition.

Laser-speckle contrast imaging and optogenetic stimulation. Mice were anesthetized with $5 \%$ isoflurane in air, and then reduced to $1-1.5 \%$ during surgery. Body temperature was maintained at $37 \pm 0.5^{\circ} \mathrm{C}$ by a heating pad which had its intensity controlled by temperature feedback from a rectal probe. The mouse was secured in a custom-made head hold using cyanoacrylate and dental cement and a craniotomy was made over the right forelimb sensorimotor cortex. The dura was left intact. Agarose dissolved in HEPES buffered aCSF, $\mathrm{pH} 7.3$, to $1.5 \%$ was placed over the surface of the cortex at $37^{\circ} \mathrm{C}$. The surface of the cortex was then covered with a no. $1130,160 \mu$ m thick glass coverslip. Before imaging, the brain was warmed to $\sim 37^{\circ} \mathrm{C}$ by pumping warm water through tubing attached to the custom built stainless steel head hold (Xie et al., 2013). During stimulation procedures anesthesia was switched to a ketamine/xylazine combination $(100 / 10 \mathrm{mg} / \mathrm{kg})$ that was supplemented as required.

The surface of the cortex was illuminated with a $784 \mathrm{~nm} 32 \mathrm{~mW}$ StockerYale SNFXXX_885 s-35 laser (Stocker and Yale) with a beam expander directed at the cortex at a $30^{\circ}$ angle. Light intensity was controlled with a polarizer. The flow of blood cells and resultant blurring in the interference patterns (Briers, 2001) was detected by a CCD camera (Dalsa 1M60). Image acquisition was performed using EPIX XCAP software (v2.2). Ten trials for each stimulation parameter consisting of 100-130 frames were acquired at 10 $\mathrm{Hz}$ with a $10 \mathrm{~ms}$ exposure time. Using MATLAB (MathWorks) each $1024 \times 1024$ pixel image in the stack was variance filtered spatially with a kernel size of 3 pixels. Blood flow measurements were estimated as the inverse square of speckle contrast values which were scaled between minimum and maximum flow rate (Cheng and Duong, 2007). Minimum flow was determined from contrast values measured from the mouse cortex after the animal was killed. For stimulation a $473 \mathrm{~nm}$ laser beam (Crystalaser, collimated to $\sim 100 \mu \mathrm{m}$ diameter, $5 \mathrm{~ms}$ pulses, $3.3 \mathrm{~mW}, 100$ $\mathrm{Hz}, 1 \mathrm{~s}$ ) was targeted to forelimb sensorimotor cortex (Scott and Murphy, 2012). Light from the $473 \mathrm{~nm}$ laser was blocked from contaminating the speckle signal as detected by the camera by a $715 \mathrm{~nm}$ long-pass filter. Regions of interest selected for assessment of speckle contrast over time were $1 \mathrm{~mm}^{2}$ and centered at the site where the laser was targeted over the cortex.

After baseline assessment of light-evoked hemodynamic responses the agarose was removed from the cortical surface and NS 398 was adminis-
B

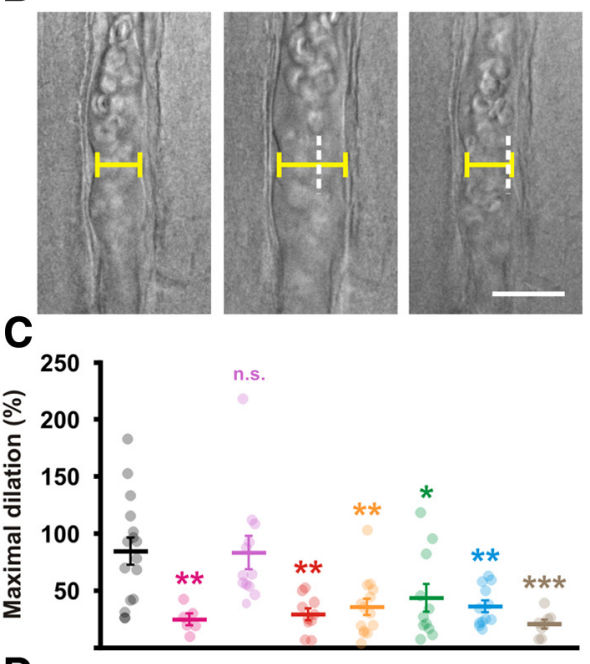

D

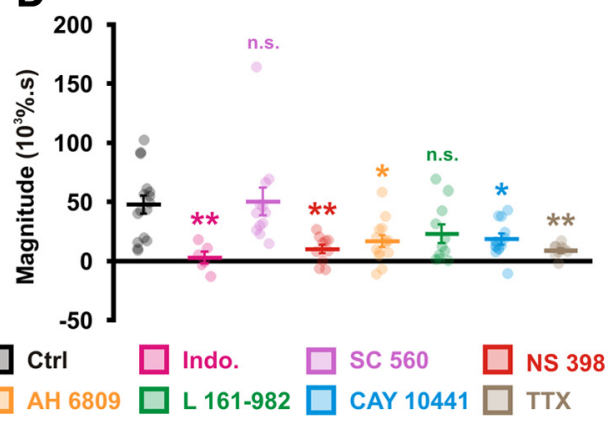

Figure 1. Characterization of NMDA-induced vasodilations. $A$, Diameter changes induced by 5 min bath applications of NMDA ( $30 \mu$; black bar and vertical gray zone). The SEM envelopes the mean traces. The horizontal dashed lines represent the initial diameters. The vertical scale bar indicates the relative diameter changes. Under control conditions (Ctrl, black, $n=16$ arterioles from 12 rats) NMDA induces vasodilations. Nonselective COX-1/2 inhibition by indomethacin (Indo; magenta, $n=6$ arterioles from ( he vascular response in contrast to the selective inhibition of COX-2 by NS 398 (red, $n=10$ arterioles from 8 rats). Antagonism of ( TTX (brown, $n=8$ arterioles from 3 rats) dramatically reduced the vascular responses. $B$, Representative example showing infrared images of a preconstricted diving arteriole that reversibly dilated to NMDA application. Pial surface is upward. Scale bar, 20

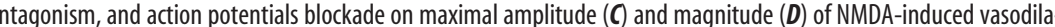
tions. Dots represent individual arteriolar responses. Bars and error bars correspond to the mean $\pm \mathrm{SEM} .{ }^{*},{ }^{* *}$, and ${ }^{* * *}$ statistically different from Ctrl condition with $p<0.05,0.01$ and 0.001 , respectively; n.s., not statistically significant.

trated directly on the cortex for $30 \mathrm{~min}$. Agarose was then reapplied to the cortex $\left(37^{\circ} \mathrm{C}\right)$, covered with a coverslip, and laser speckle contrast imaging ensued. The magnitude of $\mathrm{CBF}$ change was defined as the integral of $\mathrm{CBF}$ changes measured from the onset of stimulation to the end of the recording.

Drugs. U46619, NMDA, SC 560, NS 398, AH 6809; and L 161-982 were purchased from Enzo Life Sciences, CAY 10441 from Cayman chemical, Indomethacin from Sigma-Aldrich and TTX from Latoxan.

Statistical analyses. Statistical analyses were performed with Prism 4 (GraphPad Software) or Statistica 6 (Statsoft). All values are expressed as mean \pm SEM. Normality of distributions and equality of variances were assessed using the Shapiro-Wilk test and the $F$ test, respectively. Parametric tests were only used if these criteria were met. Bonferroni correction was used for multiple comparisons. Statistical significance on all figures uses the following convention: ${ }^{\star} p<0.05,{ }^{\star *} p<0.01,{ }^{* *} p<0.001$.

Statistical significance of vascular responses, morphological and electrophysiological properties, and light-induced CBF responses between Thy1-YFP and Emx1-Cre;Ai32 mice was determined using the MannWithney $U$ test. Comparison of the occurrence of expressed genes between different cell types was determined using Fisher's exact test. 
Table 3. In vitro $\mathrm{IC}_{50}$ and concentrations of various $\mathrm{COX}$ inhibitors and prostaglandin receptor antagonists used for inhibition in tissue

\begin{tabular}{|c|c|c|c|c|}
\hline \multirow[b]{2}{*}{ Inhibitor/antagonist } & \multirow[b]{2}{*}{ In vitro $\mathrm{IC}_{50}\left(\right.$ or $\left.\mathrm{K}_{\mathrm{i}}\right)$} & & \multicolumn{2}{|c|}{ Concentrations used for inhibition in brain tissue } \\
\hline & & & Preparation & Concentration \\
\hline Indomethacin & $\begin{array}{l}\text { COX-1: } 22 \text { nм } \\
\text { (Lora et al., 1998) }\end{array}$ & $\operatorname{COX}-2: 87 \mathrm{~nm}$ & $\begin{array}{l}\text { Brain slices } \\
\text { (Zonta et al., 2003) }\end{array}$ & $5 \mu \mathrm{M}$ \\
\hline SC 560 & $\begin{array}{l}\text { COX-1: } 9 \text { nm } \\
\text { (Smith et al., 1998) }\end{array}$ & $\operatorname{COX}-2: 6.3 \mu \mathrm{M}$ & $\begin{array}{l}\text { Brain slices } \\
\text { (Blanco et al., 2008) }\end{array}$ & $100 \mathrm{~nm}$ \\
\hline NS 398 & $\begin{array}{l}\text { COX-1: } 50 \mu \mathrm{M} \\
\text { (Lora et al., 1998) }\end{array}$ & $\operatorname{COX}-2: 0.6 \mu \mathrm{M}$ & $\begin{array}{l}\text { Brain slices } \\
\text { (Slanina and Schweitzer, 2005) }\end{array}$ & $10 \mu \mathrm{M}$ \\
\hline AH 6809 & $\begin{array}{l}\text { EP1: } 1.3 \mu \mathrm{M}\left(\mathrm{K}_{\mathrm{i}}\right) \\
\text { (Boie et al., 1997) }\end{array}$ & EP2: $0.5 \mu \mathrm{M}\left(\mathrm{K}_{\mathrm{i}}\right)$ & $\begin{array}{l}\text { Isolated cerebrovascular arterioles } \\
\text { (Myren et al., 2010; Dabertrand et al., 2013) }\end{array}$ & $10 \mu \mathrm{M}$ \\
\hline L 161-982 & $\begin{array}{l}\text { EP4: } 100 \mathrm{~nm} \\
\text { (Machwate et al., 2001) }\end{array}$ & & $\begin{array}{l}\text { Brain slices } \\
\text { (Hall et al., 2014) }\end{array}$ & $1 \mu \mathrm{M}$ \\
\hline CAY 10441 & $\begin{array}{l}\text { IP: } 7 \text { nm } \\
\text { (Bley et al., 2006) }\end{array}$ & & Not available & \\
\hline
\end{tabular}
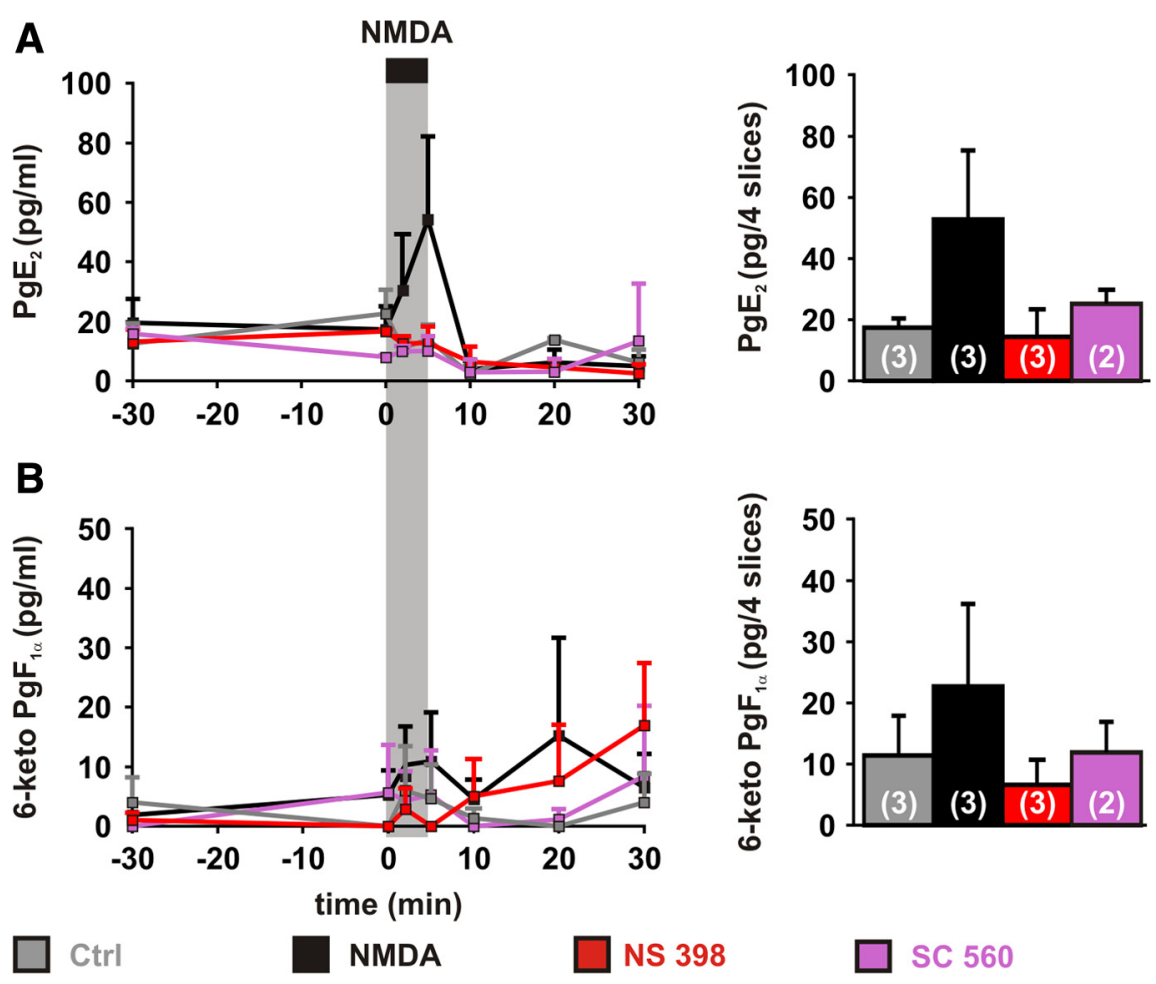

Figure 2. Vasodilatory prostaglandins release dynamics induced by NMDA. Dynamics of $\operatorname{PgE}_{2}(\boldsymbol{A})$ and 6-keto $\operatorname{PgF}_{1 \alpha}(\boldsymbol{B})$ levels in the supernatants (left) and in the slices after treatments (right). Samples were collected before adding COX inhibitors $(t=-30)$, before ( $t=0 \mathrm{~min}$ ) and during ( $t=2$ and $5 \mathrm{~min}$ ) NMDA ( $30 \mu \mathrm{m}$; black bar and vertical gray zone), and after removing NMDA ( $t=$ 10, 20 and $30 \mathrm{~min}) \cdot \operatorname{PgE}_{2}(\boldsymbol{A})$ and to a lesser extent and 6-keto $\operatorname{PgF}_{1 \alpha}(\boldsymbol{B})$ levels increased during NMDA application (NMDA, black traces) but not after NMDA removal. No change was observed when applying NMDA vehicle (water, Ctrl, gray traces) or when NMDA was applied in presence of NS 398 (red traces) or SC 560 (purple traces). Tissue content (right) in $\mathrm{PgE}_{2}(\boldsymbol{A})$ and 6-keto $\mathrm{PgF}_{1 \alpha}$ $(B)$ were elevated when slices were treated with NMDA in absence of COX inhibitor. Numbers in parenthesis represent the number of replicates. Error bars are SEM.

Statistical significance of light-induced CBF responses before and after NS 398 application was determined using a paired $t$ test. Drug effects on $\mathrm{CBF}$ (at the maximum dose and time efficacy determined in preliminary experiments), LFP, blood gases, blood pressure measurements, and prostaglandin analysis were compared by repeated-measures ANOVA, followed by a post hoc Newman-Keuls test between each condition. When normality of distribution was not met, the Friedman test was used.

\section{Results}

COX-2-derived prostaglandins mediate

NMDA-induced vasodilations

To identify the prostaglandins involved in NVC, we focused on NMDA receptors for the following reasons: (1) their activation promotes in vivo the release of the vasodilatory $\mathrm{PgE}_{2}$ and $\mathrm{PgI}_{2}$ (Lazarewicz and Salińska, 1995; Pepicelli et al., 2005). (2) Similar to COX-2, their activity accounts for approximately one-half of the NVC responses to various sensory stimuli (Niwa et al., 2000; Norup and Lauritzen, 2001; Bakalova et al., 2002; Gsell et al., 2006; Stefanovic et al., 2006; Lecrux et al., 2011). (3) NMDA receptors blockade occludes the reduction of the NVC responses induced by COX-2 inhibition (Lecrux et al., 2011), suggesting that most of the NVC response evoked by NMDA receptors is due to the release and action of vasodilatory prostaglandins. Finally, (4) NMDA has been shown to dilate cortical arterioles in acute cortical slices (Fergus and Lee, 1997; Lovick et al., 1999).

Because the brain slice preparation offers a well controlled extracellular environment suitable for pharmacological manipulations (Iadecola and Nedergaard, 2007) and prostaglandin measurement (Gordon et al., 2008), we first sought to determine whether vasodilatory prostaglandins could mediate the NMDA-induced vasodilations in young rats. We chose this approach as a good compromise for preservation of slice quality, easily achieved in young animals and essential to preserve neurovascular physiology, and a phenotype of the neuro-glio-vascular unit close to adulthood (Mishra et al., 2014). Indeed, COX-2 expression (Yamagata et al., 1993; Kaufmann et al., 1996; Tocco et al., 1997), astrocyte phenotype (Stichel et al., 1991; Zhou et al., 2006; Houades et al., 2008) and vascular patterns (Harb et al., 2013; Whiteus et al., 2013; Lacoste et al., 2014) maturate during the end of the third postnatal week.

We used $30 \mu \mathrm{M}$ NMDA, a submaximal concentration eliciting large vasodilations (Fergus and Lee, 1997) compatible with their pharmacological investigations (Mishra et al., 2014). Bath application of NMDA, dilated preconstricted cortical arterioles (maximal dilation $84.7 \pm 11.9 \%$, magnitude $47.7 \pm 7.610^{3} \%$ •s; Fig. 1; Table 1; Movie 1). In a majority of arterioles ( $n=10$ of 16 ), NMDA did not fully bring back luminal diameters to their preconstriction value $(83.2 \pm 3.5 \%)$. How- 
ever in some cases $(n=6$ of 16) it further dilated arterioles by $12.0 \pm$ $3.5 \%$.

To evaluate whether the biosynthesis of vasodilatory prostaglandins was involved, slices were pretreated with the nonselective COXs inhibitor indomethacin at $5 \mu \mathrm{M}$ (Table 3 ). This treatment abolished almost completely the NMDA responses (maximal dilation: $25.0 \pm 5.0 \%, p=0.002412, \mathrm{U}_{(16,6)}=9$, Mann-Whitney $U$ test; magnitude: $2.9 \pm 5.010^{3} \% \cdot \mathrm{s}, p=$ $0.000804, U_{(16,6)}=6$, Mann-Whitney $U$ test; Fig. 1) indicating that vasodilatory prostaglandins are recruited during NMDAinduced vasodilations. We next determined the relative contribution of COX-1 and COX-2 to these responses. Selective COX-1 inhibition with SC 560 (100 nM; Table 3) did not alter the maximal amplitude $\left(83.5 \pm 14.7 \%, p=0.766584, U_{(16,12)}=\right.$ 89 , Mann-Whitney $U$ test) or the magnitude of the vasodilations $\left(50.2 \pm 11.910^{3}\right.$ $\% \cdot s, p=0.873052, U_{(16,12)}=92$, MannWhitney $U$ test; Fig. 1). However, during the $5 \mathrm{~min}$ of NMDA application the peak of vasodilation was lower in the presence of SC $560(17.0 \pm 4.9 \%)$ than in control condition $(38.2 \pm 8.4 \%, p=$ $0.000204, U_{(16,12)}=16$, Mann-Whitney $U$ test; Fig. $1 A$ ), suggesting that COX-1derived prostaglandins may participate in the initial phase of the NVC response.

In contrast with SC 560, and similarly to indomethacin, selective COX-2 inhibition with NS 398 (10 $\mu \mathrm{M}$; Table 3) dramatically reduced the maximal amplitude $\left(29.3 \pm 5.3 \%, p=0.000555, U_{(16,10)}=18\right.$, Mann-Whitney $U$ test; Fig. 1) and magnitude of the response $\left(10.1 \pm 3.810^{3} \% \cdot \mathrm{s}\right.$, $p=0.000910, U_{(16,10)}=20$, Mann-Whitney $U$ test; Fig. 1). NS 398 strongly diminished the maximal response during the 5 min of NMDA application $(14.1 \pm 4.1 \%$, $p=0.000025, U_{(16,10)}=0$, Mann-Whitney $U$ test; Fig. $1 A$ ). Similarly to the in vivo context (Niwa et al., 2000, 2001; Bakalova et al., 2002; Stefanovic et al., 2006; Lecrux et al., 2011) our observations demonstrate a prominent role of COX-2 metabolites in NVC validating therefore this ex vivo approach. We also report that the initial phase of the NVC response to NMDA is sensitive to SC 560 and NS 398.

To identify the nature of the dilatory prostaglandins involved, we antagonized the vasodilatory $\mathrm{PgE}_{2}$ and $\mathrm{PgI}_{2}$ receptors. Since there is no commercially available selective EP2 antagonist, we used the EP2/ EP1 antagonist AH 6809 (10 $\mu$ M; Table 3). AH 6809 strongly reduced the maximal amplitude $(35.8 \pm 7.2 \%, p=0.002069$, $U_{(16,14)}=40$, Mann-Whitney $U$ test; Fig. 1$)$ and the magnitude of NMDA-induced vasodilations $\left(16.7 \pm 4.910^{3} \% \cdot s, p=\right.$ $0.003321, U_{(16,14)}=43$, Mann-Whitney $U$ test; Fig. 1). We next thought to block EP4 receptors with its selective antagonist L 161-982 (1 $\mu \mathrm{M}$; Table 3). L 161-982 significantly impaired the maximal amplitude $\left(43.8 \pm 11.9 \%, p=0.019827, U_{(16,11)}=41\right.$, Mann-Whitney $U$ test; Fig. 1) but not the magnitude of vasodilations $\left(23.0 \pm 7.8 \% 10^{3} \% \cdot s, p=0.026246, U_{(16,11)}=43\right.$, Man-
Table 4. In vivo neurovascular coupling response impairment by receptor antagonists

\begin{tabular}{llcr}
\hline Antagonist & Concentration & $\begin{array}{l}\text { Effect on the peak CBF } \\
\text { whisker response }\end{array}$ & $n$ \\
\hline AH 6809 & $10^{-7} \mathrm{M}$ & $-5.7 \pm 4.5 \%$ & 4 \\
& $10^{-6} \mathrm{M}$ & $-28.2 \pm 2.6 \%$ & 5 \\
& $10^{-5} \mathrm{M}$ & $-15.0 \pm 3.8 \%$ & 6 \\
& $10^{-4} \mathrm{M}$ & $-6.1 \pm 3.8 \%$ & 5 \\
L 161-982 & $10^{-4} \mathrm{M}$ & $-17.7 \pm 4.8 \%$ & 4 \\
CAY 10441 & $10^{-6} \mathrm{M}$ & $+10.2 \pm 11.8 \%$ & 3 \\
& $10^{-5} \mathrm{M}$ & $+10.4 \pm 22.1 \%$ & 3 \\
& $10^{-4} \mathrm{M}$ & $+0.6 \pm 8.7 \%$ & 5 \\
\hline
\end{tabular}
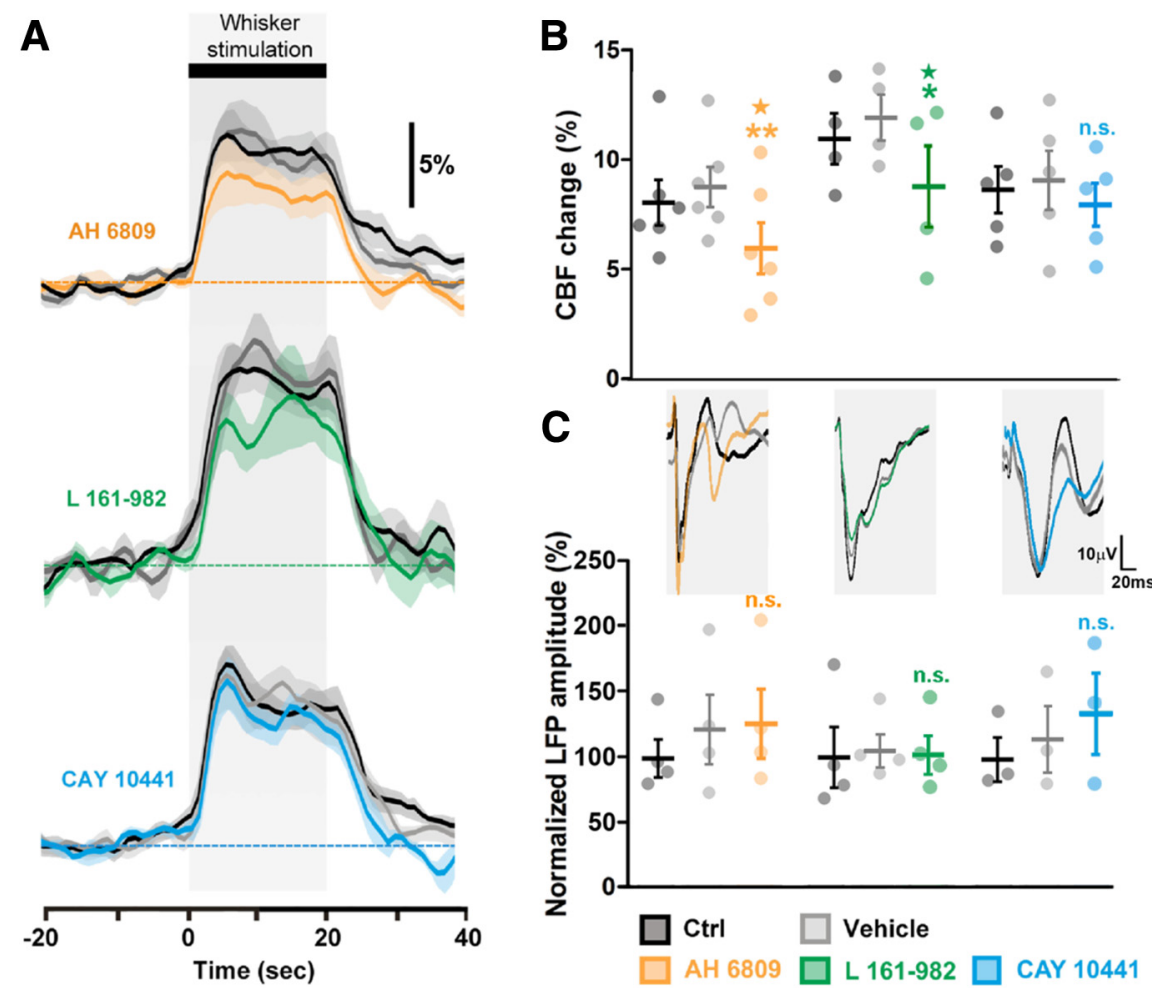

Figure 3. Effects of EP2, EP4, and IP receptors blockade on the NVC response to sensory stimulation. $\boldsymbol{A}$, Whisker stimulation (gray zone, top black bar) induced increases in CBF in the contralateral barrel cortex under control conditions (Ctrl; black lines). The evoked response was not altered by vehicle (gray line), whereas the EP1/EP2 receptor antagonist AH 6809 (orange, $n=6$ rats) and EP4 receptor antagonist L 161-982 (green, $n=4$ rats), but not the IP receptor antagonist CAY 10441 (blue, $n=5$ rats), decreased this response. The SEM envelopes the mean traces. $\boldsymbol{B}, \boldsymbol{C}$, Maximal whisker-evoked changes in $\operatorname{CBF}(\boldsymbol{B})$ and in $\operatorname{LFP}(\boldsymbol{C})$, under baseline (CBF: $8.0 \pm 1.1 \%, 10.9 \pm 1.3 \%$, and $8.6 \pm 1.2 \% ;$ LFPs: $100.0 \pm 16.7 \%, 100.0 \pm 27.0 \%$, and $100.0 \pm 20.8 \%$ ) and vehicle (CBF: $8.7 \pm 1.0 \%, 11.9 \pm 1.2 \%$ and $9.0 \pm 1.5 \%$; LFPs: $122.3 \pm 30.8 \%, 105.0 \pm 14.6 \%$, and $115.4 \pm 31.3 \%)$ conditions and application of AH 6809 (CBF: $5.9 \pm 1.3 \%$; LFPs: $126.6 \pm 30.8, n=6$ and 4 rats, respectively), L 161-982 (CBF: $8.7 \pm 2.1 \%$; LFPs: $101.9 \pm 17.0 \%, n=4$ rats) or CAY 10441 (CBF: $7.9 \pm 1.1 \%$; LFPs: $135.0 \pm 38.4 \%, n=5$ and 3 rats, respectively). Whisker stimulation induced increases in the amplitude of the LFPs in the contralateral barrel cortex as shown by the representative tracings (average of 7 trials from $1 \mathrm{rat}$ ) for each compound ( $\boldsymbol{C}$, top). Contralateral LFP amplitudes were normalized by the mean amplitude under baseline conditions. ${ }^{*} p<0.05$ and ${ }^{* *} p<0.01$ compared with vehicle conditions, $\star p<0.05$ compared with Ctrl conditions, n.S., not statistically significant. Dots represent individual responses. Horizontal bars and error bars represent mean \pm SEM.

n-Whitney $U$ test; Fig. 1). Blockade of IP receptor was achieved with CAY 10441 (200 nM; Table 3). CAY 10441 reduced the maximal amplitude $\left(36.3 \pm 5.2 \%, p=0.000670, U_{(16,12)}=26\right.$, Mann-Whitney $U$ test; Fig. 1) and the magnitude of vasodilations $\left(18.5 \pm 4.610^{3} \% \cdot s, p=0.003711, U_{(16,12)}=35\right.$, Mann-Whitney $U$ test; Fig. 1). The reduction of NMDA-induced vasodilations by EP2, EP4, and IP receptor antagonists and during COX-2 or COX-1 inhibition suggests that $\mathrm{PgE}_{2}$ and $\mathrm{PgI}_{2}$ essentially derived from COX-2 activity underlie these vascular responses. 
Table 5. Physiological parameters in rats during whisker stimulation

\begin{tabular}{|c|c|c|c|c|c|c|}
\hline Compound & Condition & $\mathrm{MAP}, \mathrm{mmHg}$ & $\mathrm{HR}$, beats/min & $\mathrm{pH}$ & $\mathrm{pCO}_{2}, \mathrm{mmHg}$ & $\mathrm{pO}_{2}, \mathrm{mmHg}$ \\
\hline \multirow[t]{2}{*}{ AH 6809} & Control & $79.1 \pm 5.6$ & $382.7 \pm 14.4$ & $7.44 \pm 0.02$ & $41.7 \pm 0.6$ & $90.7 \pm 3.2$ \\
\hline & Vehicle & $78.9 \pm 5.8$ & $374.6 \pm 17.5$ & $7.43 \pm 0.01$ & $42.7 \pm 1.6$ & $91.3 \pm 3.0$ \\
\hline \multirow{4}{*}{$\begin{array}{l}\text { MAP, HR } \\
\text { ( } n=6 \text { rats) } \\
\mathrm{pH}(n=4 \text { rats) } \\
\mathrm{pCO}_{2}, \mathrm{pO}_{2} \\
\text { ( } n=5 \text { rats) }\end{array}$} & Drug & $79.2 \pm 5.3$ & $376.7 \pm 20.3$ & $7.44 \pm 0.01$ & $41.3 \pm 0.9$ & $90.0 \pm 3.0$ \\
\hline & & $Q_{(2,6)}=1.00000$ & $Q_{(2,6)}=0.3333333$ & $Q_{(2,4)}=1.50000$ & $F_{(2,8)}=0.04450$ & $F_{(2,8)}=1.027$ \\
\hline & & $p=0.60653$ & $p=0.84648$ & $p=0.47237$ & $p=0.9074$ & $p=0.3974$ \\
\hline & & n.s. & n.s. & n.s. & n.s. & n.s. \\
\hline \multirow[t]{2}{*}{ L 161-982 } & Control & $74.7 \pm 4.9$ & $398.2 \pm 37.3$ & $7.42 \pm 0.01$ & $36.0 \pm 4.8$ & $101.1 \pm 9.7$ \\
\hline & Vehicle & $74.3 \pm 6.5$ & $401.9 \pm 43.8$ & $7.43 \pm 0.01$ & $38.5 \pm 1.6$ & $91.4 \pm 1.5$ \\
\hline \multirow{4}{*}{$\begin{array}{l}\mathrm{MAP}, \mathrm{HR}, \mathrm{pH}, \mathrm{pO}_{2} \\
\text { ( } n=4 \text { rats) } \\
\mathrm{pCO}_{2} \\
\text { ( } n=3 \text { rats) }\end{array}$} & Drug & $73.5 \pm 6.8$ & $377.5 \pm 30.0$ & $7.42 \pm 0.02$ & $36.3 \pm 3.8$ & $105.6 \pm 7.7$ \\
\hline & & $F_{(2,6)}=0.1294$ & $F_{(2,6)}=2.689$ & $F_{(2,6)}=0.2572$ & $F_{(2,4)}=0.7467$ & $F_{(2,6)}=1.621$ \\
\hline & & $p=0.8037$ & $p=0.1930$ & $p=0.7263$ & $p=0.4786$ & $p=0.2923$ \\
\hline & & n.s. & n.s. & n.s. & n.s. & n.s. \\
\hline \multirow[t]{2}{*}{ CAY 10441} & Control & $76.1 \pm 5.2$ & $384.3 \pm 13.0$ & $7.42 \pm 0.01$ & $38.4 \pm 2.8$ & $96.6 \pm 1.7$ \\
\hline & Vehicle & $78.3 \pm 6.6$ & $394.3 \pm 16.8$ & $7.42 \pm 0.01$ & $40.9 \pm 2.0$ & $93.4 \pm 3.4$ \\
\hline \multirow[t]{3}{*}{ ( $n=5$ rats $)$} & Drug & $77.5 \pm 6.1$ & $371.2 \pm 14.8$ & $7.42 \pm 0.02$ & $38.8 \pm 1.9$ & $89.9 \pm 3.6$ \\
\hline & & $\begin{array}{l}F_{(2,8)}=1.046 \\
p=0.3676\end{array}$ & $\begin{array}{l}F_{(2,8)}=2.112 \\
p=0.2090\end{array}$ & $\begin{array}{l}Q_{(2,5)}=1.20000 \\
p=0.54881\end{array}$ & $\begin{array}{l}Q_{(2,5)}=2.80000 \\
p=0.2466\end{array}$ & $\begin{array}{l}F_{(2,8)}=4.616 \\
p=0.0970\end{array}$ \\
\hline & & n.s. & n.s. & n.s. & n.s. & n.s. \\
\hline
\end{tabular}

Mean arterial blood pressure (MAP), heart rate ( $\mathrm{HR}), \mathrm{pH}$, and blood gases $\left(\mathrm{pCO}_{2}\right.$ and $\mathrm{pO}_{2}$ ) were measured during whisker-induced (BF responses under control conditions, as well as after vehicle and drug infusion. None of the compounds used affected physiological parameters. The number of rats is indicated within parentheses. Repeated-measures ANOVA $(F)$ or Friedman test $(Q)$ and corresponding exact $p$ values. n.s.; not statistically significant.
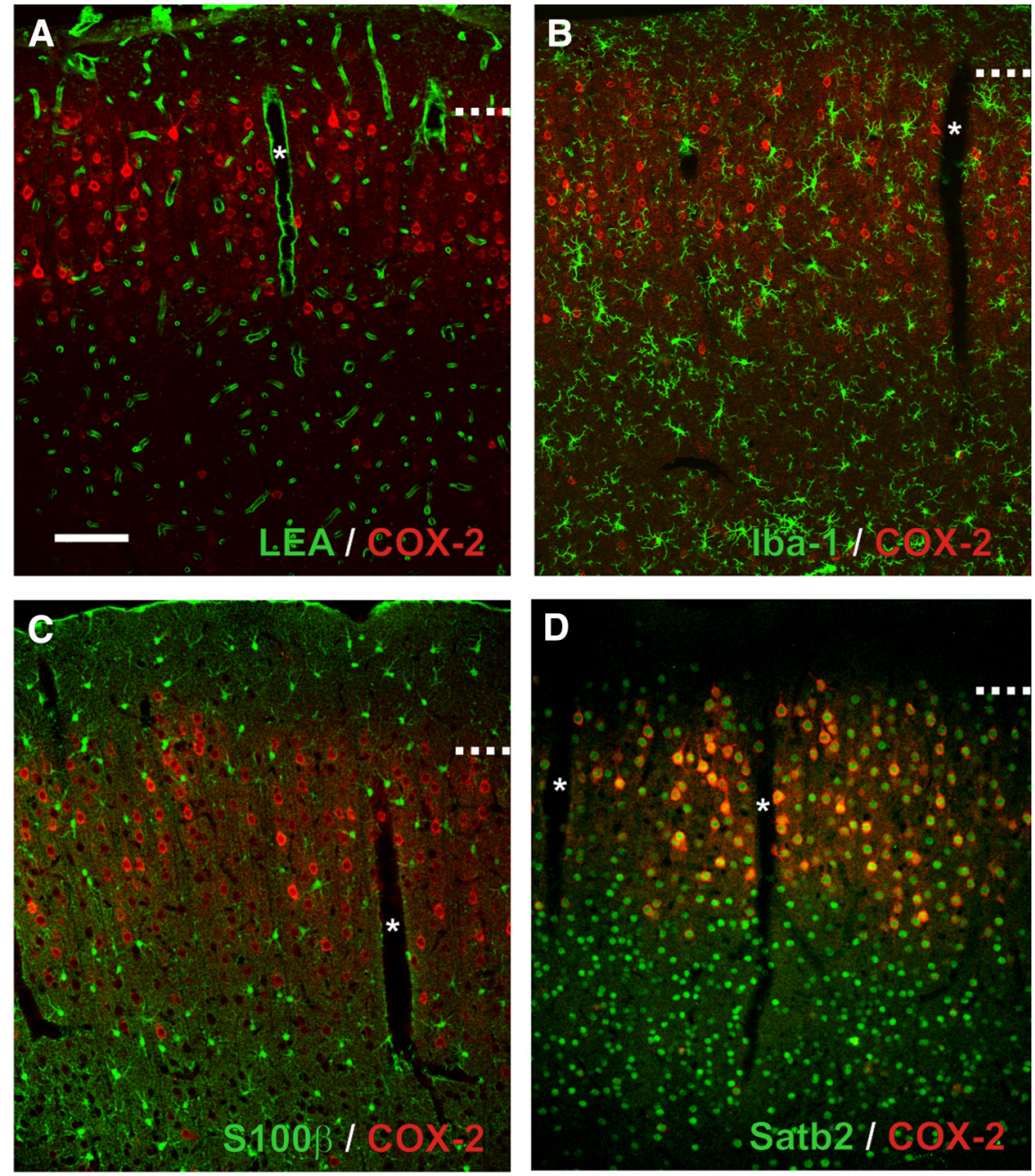

Figure 4. Expression of COX-2 in the neuro-glio-vascular unit. Representative single plane confocal images of double fluores cence staining showing the constitutive expression of COX-2 (red). Scale bar, $100 \mu \mathrm{m}$. *Denotes diving blood vessels. Dashed lines represent layer I-II border. Pial surface is upward. $\boldsymbol{A}$, COX-2 immunolabeling is absent from the vascular bed stained with LEA (green) and (B) from microglia immunostained for lba-1. C, S100 $\beta$ immunostained astrocytes (green) are essentially COX-2negative. $\boldsymbol{D}$, COX-2-immunopositive cells are Satb2-positive (green).
NMDA promotes the biosynthesis and release of $\mathrm{PgE}_{2}$ and $\mathrm{PgI}_{2}$ in cortical slices

To confirm that $\mathrm{PgE}_{2}$ and $\mathrm{PgI}_{2}$ are indeed produced and released by NMDA applications we sought to measure the content in $\mathrm{PgE}_{2}$ and 6-keto prostaglandin $\mathrm{F}_{1} \alpha$ (6keto $\mathrm{PgF}_{1 \alpha}$ ), the stable metabolite of $\mathrm{PgI}_{2}$, produced in slices before, during and after NMDA application in presence or absence of COX inhibitors (Fig. 2). Prostaglandins and thromboxane were measured by LC-ESI-MS/MS which permits an unambiguous identification of prostaglandins (Schmidt et al., 2005, 2014). Because the amount of $\mathrm{PgE}_{2}$ that can be released by slices is very low (Gordon et al., 2008), four slices were coincubated each time. Prostaglandin analysis was performed in the supernatant at different time points and in the tissue at the end of the treatments (Fig. 2).

The temporal profile of $\mathrm{PgE}_{2}$ content (Fig. $2 A$ ) was significantly altered when slices were treated by NMDA ( $p=$ $0.00514, Q_{(7,3)}=20.21$, Firedman test), but not when NMDA was omitted ( $p=$ 0.09697, $Q_{(7,3)}=12.11$, Firedman test) or when NMDA was applied in presence of NS $398\left(p=0.19886, Q_{(7,3)}=9.82\right.$, Firedman test) or SC $560\left(p=0.19417, Q_{(7,2)}\right.$ $=9,90$, Firedman test). Similarly to $\mathrm{PgE}_{2}$, the temporal profile of 6-keto $\mathrm{PgF}_{1 \alpha}$ (Fig. $2 B)$ was modified by NMDA treatment $\left(p=0.03266, Q_{(7,3)}=15.27\right.$ with $\mathrm{NMDA}$ and $p=0.24846, Q_{(7,3)}=9,06$ without NMDA, Firedman tests) but not in presence of NS $398\left(p=0.34416, Q_{(7,3)}=\right.$ 7.87, Firedman test) or SC 560 ( $p=$ $0.49799, Q_{(7,2)}=6,36$, Firedman test). 

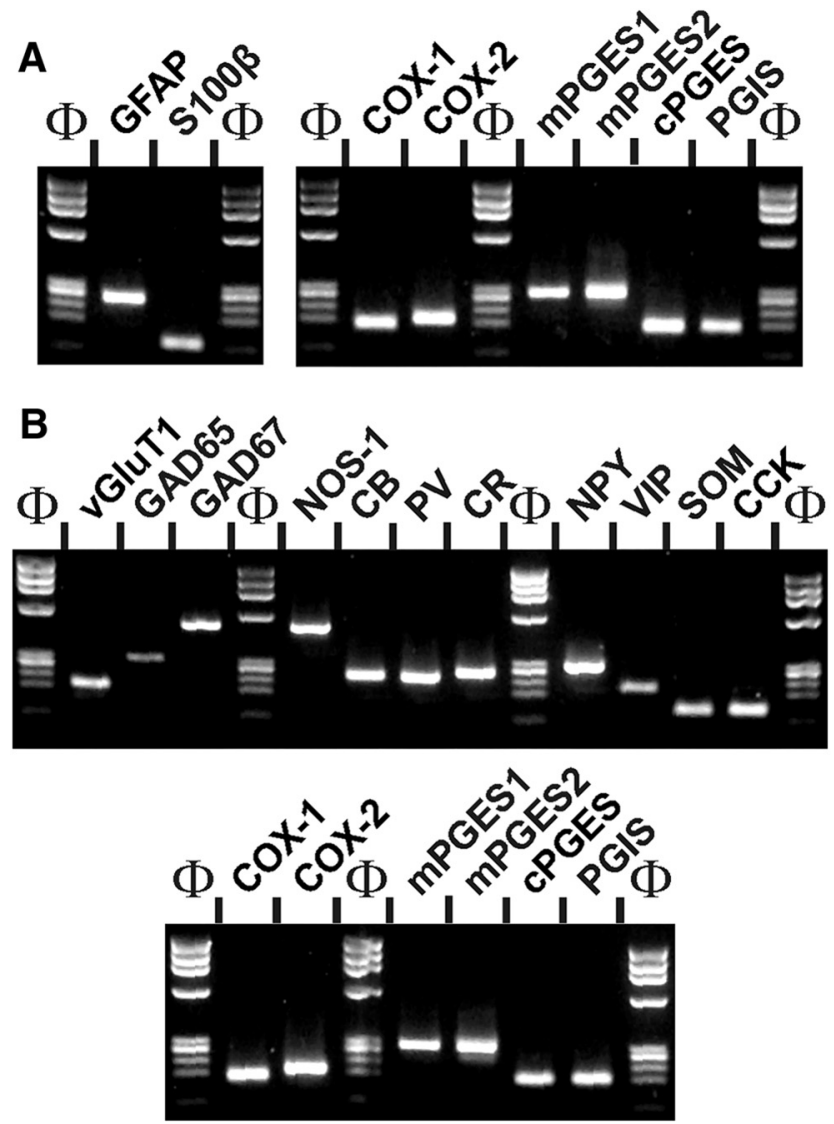

Figure 5. Sensitivity of RT-mPCR protocols. Total cortical RNAs $(500 \mathrm{pg})$ were subjected to RT-PCR protocols designed for the molecular characterization of perivascular astrocytes $(\boldsymbol{A})$ and cortical neurons $(\boldsymbol{B})$. The $P C R$ products were resolved in separate lanes by agarose gel electrophoresis in parallel with $\Phi \times 174$ digested by Haell as molecular weight marker and stained with ethidium bromide. The amplified fragments corresponding to astrocytic ( $\boldsymbol{A}$, left) and neuronal ( $\boldsymbol{B}$, top) molecular markers, as well as $\mathrm{PgE}_{2}$ and $\mathrm{Pgl}_{2}$ synthesizing enzymes ( $\boldsymbol{A}$, right, $\boldsymbol{B}$, bottom) had the size predicted by their mRNA sequence (Table 2).

$\mathrm{PgE}_{2}$ content in the supernatant reached a maximum of $54 \pm$ $28 \mathrm{pg} / \mathrm{ml}$ ) $5 \mathrm{~min}$ after the application of NMDA (Fig. 2A) and remained elevated in the tissue after NMDA treatment without COX inhibitor $(32 \pm 22 \mathrm{pg} / 4$ slices). Although in the supernatant the content in 6-keto $\mathrm{PgF}_{1 \alpha}$ was often below the lower limit of quantification (see Materials and Methods), during NMDA application a maximal level of 6-keto $\operatorname{PgF}_{1 \alpha}(9 \pm 8 \mathrm{pg} / \mathrm{ml})$ could be reached after $5 \mathrm{~min}$ and was reliably quantifiable in the tissue after NMDA treatment without COX inhibitor $(23 \pm 13 \mathrm{pg} / 4$ slices; Fig. 2B).

Similarly to previous in vivo observations (Lazarewicz and Salińska, 1995; Pepicelli et al., 2005; Anrather et al., 2011), our ex vivo data confirm that NMDA promotes the release of $\mathrm{PgE}_{2}$ and, to a lesser extent, of 6-keto $\mathrm{PgF}_{1 \alpha}$, dependent on COX-1 and COX-2 activity, hence supporting the recruitment of the $\mathrm{PgE}_{2}$ and $\mathrm{PgI}_{2}$ vasodilatory receptors in NMDA-induced vasodilations.

\section{The NVC response to sensory stimulation recruits $\mathrm{PgE}_{2}$ vasodilatory receptors}

Our ex vivo data have indicated that NMDA-induced vasodilations are mediated by the release of $\mathrm{PgE}_{2}$ and $\mathrm{PgI}_{2}$ chiefly derived form COX-2 activity and activation of EP2, EP4, and IP receptors. Because NVC responses to sensory stimulations also involve NMDA receptors and COX-2 metabolites (Niwa et al., 2000; No- rup and Lauritzen, 2001; Bakalova et al., 2002; Gsell et al., 2006; Stefanovic et al., 2006; Lecrux et al., 2011) we sought to determine whether EP2, EP4, and IP receptors were involved in the NVC response to sensory stimulation and in adult animals.

It has been recently estimated that in vivo the majority of the CBF increase in response to sensory stimulation is mediated by capillaries dilation (Hall et al., 2014). We used LDF to obtain a global readout of CBF changes including layer IV of the somatosensory cortex which exhibits the highest neuronal and capillary density (Woolsey et al., 1996; Tsai et al., 2009) and where the NVC response initiates and propagates to upstream diving arterioles (Silva and Koretsky, 2002; Tian et al., 2010; Hall et al., 2014; Filosa et al., 2015). Indeed, with appropriate laser wavelength, fiber diameter and source-detector separation (see Materials and Methods) it has been estimated that LDF samples $\sim 1 \mathrm{~mm}^{3}$ of tissue at a depth down to $680 \mu \mathrm{m}$ (Fredriksson et al., 2009). $\mathrm{PgE}_{2}$ and $\mathrm{PgI}_{2}$ receptor antagonists were delivered by a single intracisternal injection. Although this strategy has proven efficient with little or no side effect on physiological parameters (Lecrux et al., 2011,2012 ), the precise concentration in the parenchyma is unknown as it is governed by diffusion and largely depends on tissue depth. We therefore tested different antagonist concentrations (Table 4). To avoid unspecific effects of the antagonists or their vehicle (Matsuura et al., 2009) at high concentrations, we did not inject drugs beyond $10^{-4 \mathrm{M}}$.

The EP2/EP1 antagonist AH 6809 was most effective at inhibiting the NVC response when delivered at $1 \mu \mathrm{M}$ (Table 4). Surprisingly, at higher concentrations the AH 6809-mediated inhibition of the NVC response was lower (Table 4). This dosedependent effect may be due to the lower affinity of AH 6809 for the EP1 receptor than for the EP2 receptor (Table 3). The combined antagonism of EP1/EP2 receptors obtained at higher doses may have unmasked the vasoconstrictory effect of EP1 receptors (Dabertrand et al., 2013) resulting in an apparent lower inhibition of the NVC response. Consistent with the results in acute slices, AH $6809(1 \mu \mathrm{M})$, reduced the NVC responses to whisker stimulation $\left(p=0.0069, F_{(2,10)}=8.54\right.$, repeated-measures ANOVA; Fig. $3 A, B)$, without altering the whisker-evoked neuronal activity measured by the amplitude of the LFPs $(p=$ 0.1453, $F_{(2,6)}=2.707$, repeated-measures ANOVA; Fig. 3C), blood gases or blood pressure (Table 5). Similarly L 161-982 (100 $\mu \mathrm{M}$; Table 4) significantly reduced the hemodynamic response $\left(p=0.0112, F_{(2,6)}=10.43\right.$, repeated-measures ANOVA; Fig. $3 A, B)$ without altering LFPs $\left(p=0.8856, F_{(2,6)}=0.1240\right.$, repeated-measures ANOVA; Fig. $3 C$ ) or physiological parameters (Table 5). In contrast with ex vivo observations, IP receptor blockade with CAY 10441, even when delivered at high concentrations $(100 \mu \mathrm{M}$; Table 4$)$, had no or virtually no effect on the evoked NVC $\left(p=0.4560, F_{(2,8)}=0.87\right.$, repeated-measures ANOVA; Fig. $3 A, B)$ and electrophysiological $\left(p=0.1412, F_{(2,4)}\right.$ $=3.323$, repeated-measures ANOVA; Fig. 3C) responses, or physiological parameters (Table 5). In line with our ex vivo data on vascular reactivity (Fig. 1) and prostaglandin analysis (Fig. 2), these in vivo observations indicate that $\mathrm{COX}$-2-derived $\mathrm{PgE}_{2}$ acting on EP2 and EP4 receptors is the main vasodilatory prostaglandin involved in NVC responses to sensory stimulations.

Pyramidal cells are the main cell type constitutively expressing COX-2

To identify the cellular sources of $\mathrm{PgE}_{2}$ in NVC, we next examined the cellular distribution of COX-2 in the different cellular elements of the neuro-glio-vascular unit. Although the NVC response initiates in layer IV of the somatosensory cortex (Silva and Koretsky, 2002; 

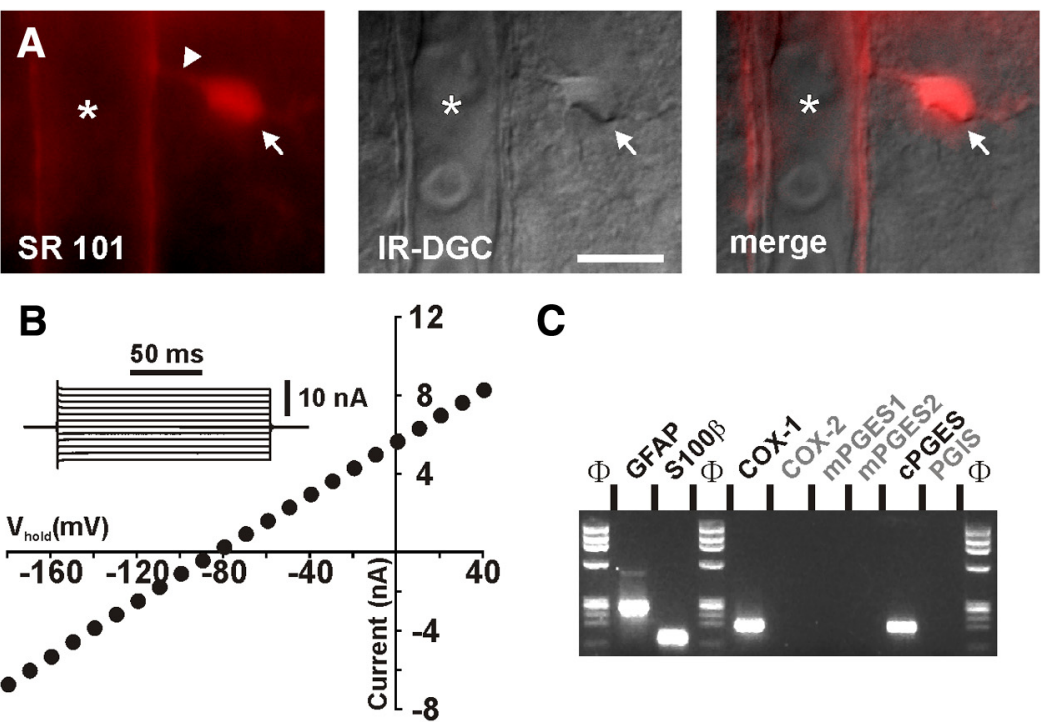

C

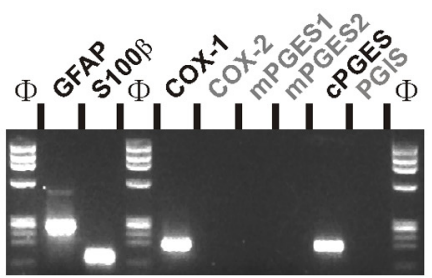

D

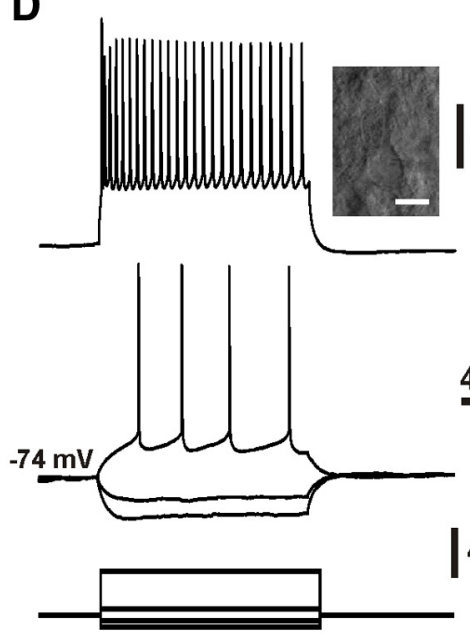

$\mathbf{F}$

\section{E}
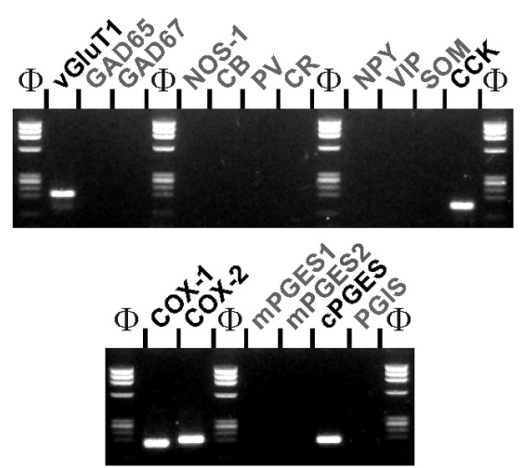

$40 \mathrm{mV}$

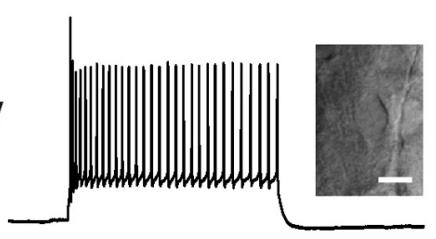

$400 \mathrm{pA}$

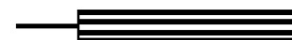

G
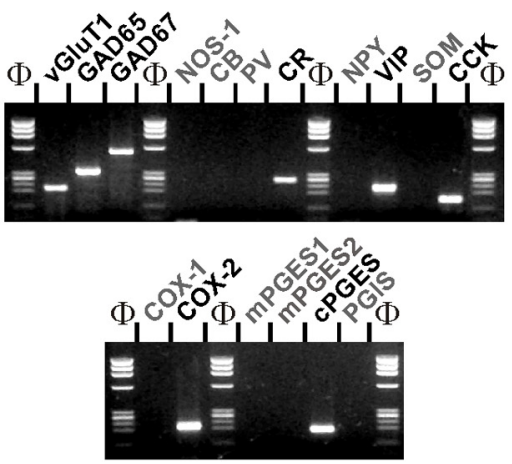

Figure 6. Characterization of prostaglandin producing cells. $A$, Vital staining of a perivascular astrocyte with SR101. Wide-field fluorescence image of the SR101-labeled cortical astrocyte (left) showing an intensely labeled cell body (arrow) sending a process (arrowhead) onto a diving arteriole ${ }^{*}$ ). Corresponding field-of-view observed under IR-DGC illumination (middle) and superimposition of the two images (right). Pial surface is upward. Scale bar, $10 \mu \mathrm{m} . \boldsymbol{B}$, Electrophysiological characterization in voltageclamp mode of the astrocyte shown in $A$. Note the linear $/ / V$ curve, the low input resistance (slope) and the hyperpolarized resting membrane potential ( $0 \mathrm{nA}$ intercept) characteristic of passive astrocytes. The inset illustrates current responses evoked by voltage steps (from -180 to $40 \mathrm{mV}, 20 \mathrm{mV}$ increments) used to determine the I/V curve at steady-state. C, scRT-PCR analysis of the same astrocyte $(\boldsymbol{A}, \boldsymbol{B})$ revealing expression of GFAP, S100 $\beta$, COX-1, and CPGES. $\boldsymbol{D}$, Voltage responses induced by injection of current pulses in a layer II-III pyramidal cell (bottom traces). Inset, IR-DGC image of the recorded cell, pial surface is upward (scale bar, 10 $\mu \mathrm{m})$. In response to just-above-threshold current pulse, this neuron fired action potentials with a long lasting biphasic AHP and little frequency adaptation (middle trace). Near saturation, it showed the typical firing of a regular spiking neuron with marked
Tian et al., 2010; Filosa et al., 2015) we focused on layers I-IV in which COX-2 cells predominates across the different cortical areas (Breder et al., 1995). Consistently, COX-2 immunolabeling obtained from 7 different rats was particularly abundant in layer II-III (Fig. 4). It mainly consisted in cytoplasmic staining and was virtually absent from the vascular bed stained with LEA (Fig. $4 A$ ) or from microglia immunostained for Iba-1 (Fig. 4B). Similarly, very few S100 $\beta$-immunolabeled astrocytes were COX-2-immunopositive $(2.1 \pm 0.9 \%, n=$ 3199 S100 $\beta$-positive cells from 4 rats; Fig. 4C). In contrast, most COX-2immunoreactive cells displayed a nucleus positive for Satb2 (Fig. 4D), a transcription factor of pyramidal cells (S. Lee et al., 2010). COX-2 cells accounted for $27.7 \pm 2.6 \%$ of Satb2 neurons $(n=6175$ Satb2-positive cells from 4 rats). This suggests that pyramidal neurons, over astrocytes, microglia, and endothelial cells, are the primary cell type constitutively expressing COX-2. Nonetheless it remains unclear whether COX-2-derived vasodilatory prostaglandins are directly produced by pyramidal neurons or if their synthesis is transcellular, as suggested for 20hydroxyeicosatetraenoic acid (Mulligan and MacVicar, 2004; Attwell et al., 2010), another arachidonic acid derivative.

Astrocytes have the capability to produce $\mathrm{PgE}_{2}$ essentially derived from COX-1 activity

To determine the capacity of astrocytes and neurons to produce $\mathrm{PgE}_{2}$ and $\mathrm{PgI}_{2}$ from arachidonic acid we assessed at the single-cell level the cellular distribution of $\mathrm{PgE}_{2}$ and $\mathrm{PgI}_{2}$ synthesizing enzymes including the rate limiting and the terminal synthesizing enzymes in young rats. Two scRT-PCR protocols were respectively designed for astrocyte and neuron characterizations. The efficiency of the protocols was tested on $500 \mathrm{pg}$ of total RNA purified

\section{$\leftarrow$}

frequency adaptation and spike amplitude accommodation (upper trace). $\boldsymbol{E}$, The pyramidal cell shown in $\boldsymbol{D}$ expressed vGluT1, CCK, COX-1, COX-2, and CPGES. $\boldsymbol{F}$, Voltage responses induced by injection of current pulses in a fusiform interneuron (bottom traces). Inset, IR-DGC image of the recorded interneuron, pial surface is upward (scale bar, $10 \mu \mathrm{m}$ ). Note the high input resistance of the cell observed at hyperpolarizing current pulses (middle traces). In response to just-above-threshold current pulse, this interneuron fired a first action potential with a monophasic AHP followed by action potentials with complex AHP. Near saturation, this neuron showed the firing of an adapting-VIP interneuron with marked frequency adaptation and spike amplitude accommodation (upper trace). $\mathbf{G}$, This interneuron expressed vGluT1, GAD65, GAD67, CR, VIP, CCK, COX-2, and CPGES. 
Table 6. Somatic properties of different cortical cells

\begin{tabular}{|c|c|c|c|}
\hline & Astrocytes $(n=44)$ & Pyramidal cells $(n=24)$ & Interneurons $(n=66)$ \\
\hline Layer & $\begin{array}{l}1.2 \pm 0.1 \\
U_{(44,24)}=46.5 \\
p=8.10^{-13}\end{array}$ & $\begin{array}{l}2.4 \pm 0.1 \\
U_{(24,66)}=748.5 \\
p=0.693357 \\
\text { Astr }<<<\text { Pyr, Int }\end{array}$ & $\begin{array}{c}2.3 \pm 0.1 \\
U_{(44,66)}=194 \\
p=4.10^{-18}\end{array}$ \\
\hline Major axis ( $\mu \mathrm{m})$ & $\begin{array}{l}18.5 \pm 0.9 \\
U_{(44,24)}=140 \\
p=9.10^{-9}\end{array}$ & $\begin{array}{l}30.2 \pm 2.0 \\
U_{(24,66)}=450 \\
p=0.001533 \\
\text { Astr }<<<\operatorname{lnt}<<\text { Pyr }\end{array}$ & $\begin{array}{l}23.9 \pm 0.8 \\
U_{(44,66)}=800 \\
p=0.00005\end{array}$ \\
\hline Minor axis $(\mu \mathrm{m})$ & $\begin{array}{c}7.9 \pm 0.3 \\
U_{(44,24)}=50 \\
p=2.10^{-12}\end{array}$ & $\begin{array}{l}14.4 \pm 0.7 \\
U_{(24,66)}=197 \\
p=4.10^{-9} \\
\text { Astr }<<<\operatorname{lnt}<<<\text { Py }\end{array}$ & $\begin{array}{c}10.3 \pm 0.2 \\
U_{(44,66)}=443 \\
p=6.10^{-11}\end{array}$ \\
\hline Elongation & $\begin{array}{c}2.4 \pm 0.1 \\
U_{(44,24)}=443 \\
p=0.28041\end{array}$ & $\begin{array}{c}2.1 \pm 0.1 \\
U_{(24,66)}=620 \\
p=0.118109\end{array}$ & $\begin{array}{c}2.3 \pm 0.1 \\
U_{(44,66)}=1432 \\
p=0.9057\end{array}$ \\
\hline Area $\left(\mu \mathrm{m}^{2}\right)$ & $\begin{array}{l}68.6 \pm 3.3 \\
U_{(44,24)}=2 \\
p=4 \cdot 10^{-18}\end{array}$ & $\begin{array}{l}208.5 \pm 13.6 \\
U_{(24,66)}=373,5 \\
p=0.000083 \\
\text { Astr }<<<\operatorname{lnt}<<<\text { Py }\end{array}$ & $\begin{array}{l}155.2 \pm 5.8 \\
U_{(44,66)}=47 \\
p=1.10^{-25}\end{array}$ \\
\hline Perimeter $(\mu \mathrm{m})$ & $\begin{array}{l}47.5 \pm 2.3 \\
U_{(44,24)}=155 \\
p=4.10^{-7}\end{array}$ & $\begin{array}{l}76.5 \pm 5.1 \\
U_{(24,66)}=359 \\
p=0.000045 \\
\text { Astr }<<\text { Int. }<<<\text { Pyr }\end{array}$ & $\begin{array}{c}56.3 \pm 1.7 \\
U_{(44,66)}=964 \\
p=0.002692\end{array}$ \\
\hline Roundness & $\begin{array}{l}2.68 \pm 0.16 \\
U_{(44,24)}=420 \\
p=0.168911\end{array}$ & $\begin{array}{l}2.27 \pm 0.18 \\
U_{(24,66)}=406 \\
p=0.000315 \\
\operatorname{lnt}<<<\text { Pyr, Astr }\end{array}$ & $\begin{array}{l}1.65 \pm 0.06 \\
U_{(44,66)}=555 \\
p=1.10^{-8}\end{array}$ \\
\hline
\end{tabular}

$\bar{n}$, Number of cells; Astr, astrocytes; Pyr, pyramidal cells; Int, interneurons. Mann-Whitney $U$ tests and corresponding exact $p$ values. $<<$ and $<<<$ indicate significantly smaller with $p<0.01$ and $<0.001$, respectively, with Bonferroni correction for multiple comparisons; n.s., not statistically significant.

from rat cerebral cortex. Figure 5 shows that for each protocol the sizes of all PCR-generated fragments were as predicted by the mRNA sequences (Table 2) and confirms the sensitivity of the scRT-PCR procedures (Cauli et al., 1997).

To facilitate astrocytes identification, slices were vitally stained with SR101 ( $n=35$ cells) or TxRed ( $n=9$ cells), two related fluorescent dyes of cortical astrocytes (Nimmerjahn et al., 2004). Labeled cells were selected in the vicinity of an arteriole (Fig. 6A) and the border of layers I and II which contain a high density of astrocytes (McCaslin et al., 2011) and the highest astrocytic molecular diversity (Zeisel et al., 2015). Cells were also selected according to the presence of a prominent perivascular process (Fig. $6 \mathrm{~A}$ ) or a cell body directly apposed to an arteriole ( $n=6$ cells). In line with their glial identity (Zhou et al., 2006), labeled cells exhibited small somata (Fig. 6A; Table 6). Whole-cell recordings revealed a linear I/V curve (Fig. 6B), a hyperpolarized membrane potential $(-87.9 \pm 1.3 \mathrm{mV})$, a low input resistance $(46.7 \pm 7.7 \mathrm{M} \Omega$ ) and an inability to generate action potentials, which are all characteristics of mature cortical astrocytes (Zhou et al., 2006; Houades et al., 2008). The molecular analysis of these cells revealed the expression of at least one of the two astrocytic markers; GFAP and S100 $\beta$ (Fig. 6C). Consistent with a low level of GFAP in quiescent cortical astrocytes (Wilhelmsson et al., 2006; Houades et al., 2008), GFAP was detected in one-half of the astrocytes, whereas S100 $\beta$ was expressed in most astrocytes ( $98 \%, n=43$ of 44 cells).

As previously observed (Takano et al., 2006; Lecrux et al., 2011), COX-1 was detected in a subpopulation of perivascular astrocytes (20\%, $n=9$ of 44 cells; Figs. $6 C$,7). In agreement with our immunohistochemical observations (Fig. $4 C$ ), a minority of S100 $\beta$-positive astrocytes expressed COX-2 (5\%, $n=2$ of 44 cells; Fig. 7). The PGES isoform, mPGES1, was never observed
(Figs. $6 C, 7 B$ ). In contrast, $\mathrm{mPGES} 2$ and cPGES were respectively detected in $5 \%(n=2)$ and $32 \%(n=14)$ of the astrocytes (Figs. $6 C, 7 B)$. PGIS was detected in 8 cells $(18 \%$; Fig. $7 A, C)$ and was systematically coexpressed with cPGES. Interestingly expression of cPGES ( $89 \%, n=8$ of 9 cells, $p=0.0001$, Fisher's exact test) and PGIS ( $44 \%, n=4$ of 9 cells, $p=0.0422$, Fisher's exact test) was enriched in COX-1-positive astrocytes. These data confirm the ability of perivascular astrocytes to synthesize COX-1-derived $\mathrm{PgE}_{2}$ (Takano et al., 2006; Gordon et al., 2008) and $\mathrm{PgI}_{2}$ to a lesser extent.

\section{Pyramidal cells are the main cell type equipped for COX-2- derived $\mathrm{PgE}_{2}$ biosynthesis}

We next characterized layer II-III neurons to confirm at the mRNA level our immunohistochemical observations (Fig. 4D) and further determine the expression profile of $\mathrm{PgE}_{2}$ and $\mathrm{PgI}_{2}$ synthesizing enzymes. Pyramidal cells were chosen on the basis of a prominent apical dendrite extending from a large triangular soma ( $n=24$ cells; Fig. $6 D$, inset; Table 6$)$. In contrast, collected interneurons ( $n=66$ cells) displayed a round ( $n=4$ cells), ovoid ( $n=16$ cells), or fusiform soma ( $n=46$ cells; Fig. $6 F$, inset). Whole-cell current-clamp recordings revealed a resting membrane potential more hyperpolarized in pyramidal cells than in interneurons (Fig. 6D,F; Table 7). Pyramidal cells fired larger and wider action potentials than interneurons (Fig. 6D, F; Table 8). They also discharged at a lower-frequency (Fig. 6D, F; Table 9). This confirms the regular spiking phenotype of pyramidal cells (McCormick et al., 1985; Cauli et al., 2000; Andjelic et al., 2009; Karagiannis et al., 2009). Consistently, the molecular analysis of pyramidal cells revealed expression of the vesicular glutamate transporter, vGluT1 (Fig. $6 E$ ) but none of the two GABA synthesizing enzymes. CCK (Fig. $6 E$ ) and, to a lesser extent, CB but not the other interneuron markers (Table 10), were frequently observed in pyramidal cells (Cauli et al., 2000; Andjelic et al., 2009; Karagiannis et al., 2009). In contrast, interneurons expressed at least one of the two GADs and frequently the interneuron markers (Fig. 6G; Table 10), particularly CR, NPY, or VIP. These electrophysiological and molecular data confirm the glutamatergic and the GABAergic phenotypes of pyramidal cells and interneurons, respectively.

COX-1 was observed in $38 \%(n=9$ of 24 ; Fig. $6 E)$ and $27 \%$ ( $n=18$ of 66$)$ of pyramidal cells and interneurons, respectively, and COX-2 in $33 \%$ of pyramidal cells ( $n=8$ of 24 cells; Figs. $6 E$, $7 A, C$ ) but only in $8 \%$ of interneurons ( $n=5$ of 66 cells; Figs. $6 G$, $7 A, C)$. Coexpression of both COX isoforms occurred in $17 \%$ of pyramidal cells (Fig. $6 E$ ) and in $5 \%$ of interneurons. Similar to astrocytes, mPGES1 was never detected in neurons (Figs. 6E, G, $7 B)$. In contradistinction, mPGES2 and cPGES were respectively detected in 29 ( $n=7$ of 24 cells) and $75 \%$ ( $n=18$ of 24 cells; Figs. $6 E, 7 B)$ of pyramidal cells and in $26(n=17$ of 66 cells $)$ and $53 \%$ $(n=35$ of 66 cells) of interneurons (Figs. $6 G, 7 B$ ). Interestingly, expression of at least one terminal $\mathrm{PgE}_{2}$ synthesizing enzyme was observed in all COX-1- or COX-2-positive pyramidal cells (Figs. $6 E, 7 C)$, and in a majority of interneurons positive for COX-1 ( $94 \%, n=17$ of 18 cells) or COX-2 (80\%, $n=4$ of 5 cells; Figs. $6 G, 7 C)$. PGIS was expressed in $25 \%$ of pyramidal cells $(n=6$ of 24 cells, Fig. $7 A, C)$ and only in $11 \%$ of interneurons $(n=7$ of 66 cells; Fig. $7 A, C$ ). These data indicate that subpopulations of cortical neurons can synthesize $\mathrm{PgE}_{2}$ and, to a lesser extent, $\mathrm{PgI}_{2}$.

The occurrence of COX-1 was similar in astrocytes, pyramidal cells, and interneurons (astrocytes vs pyramidal cells, $p=0.1563$, astrocytes vs interneurons, $p=0.5006$; pyramidal cells vs interneurons, $p=0.4364$, Fisher's exact tests; Fig. $7 A, C)$. In con- 


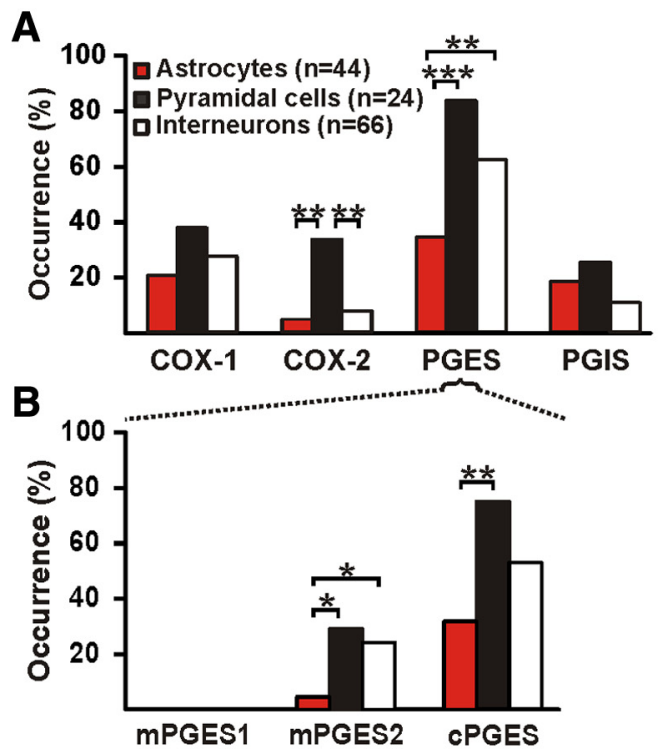

\section{C}

\section{Astrocytes \\ Pyramidal cells}
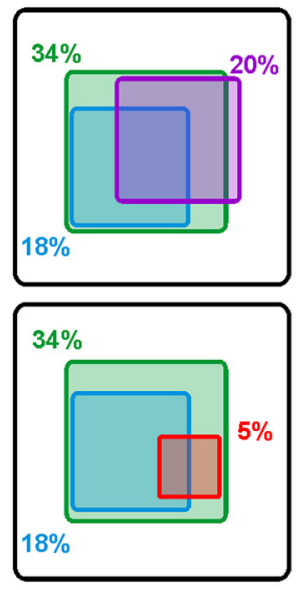

S100//GFAP
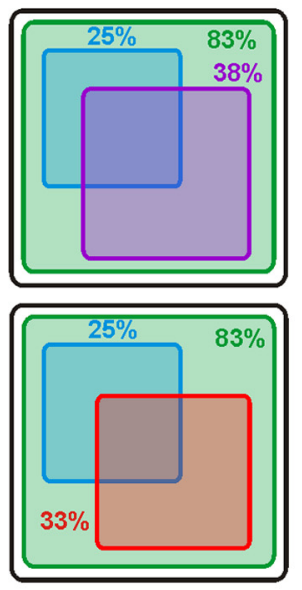

vGluT1

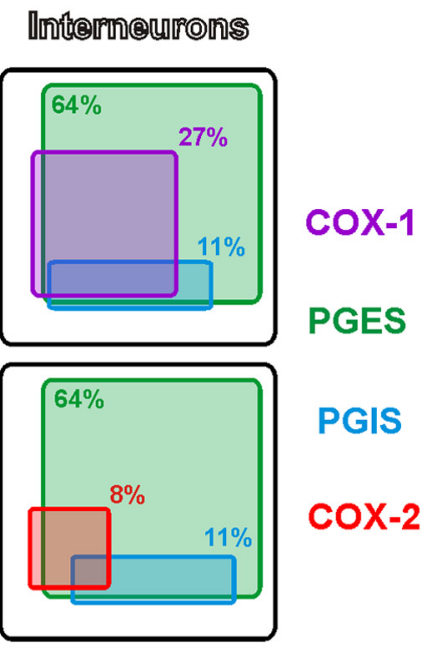

(GADB5//67

Figure 7. Expression profiles of the $\mathrm{PgE}_{2}$ and $\mathrm{Pgl}_{2}$ synthesizing enzymes. $A$, Histograms depicting the occurrence of prostanoid synthesizing enzymes in identified cell types. $\mathrm{PGES}$ denotes expression of $\mathrm{mPGES1}$, 2, and/or CPGES. Layer II-III cortical pyramidal neurons ( $n=24$ cells, black) express much more frequently COX-2, than perivascular astrocytes ( $n=44$ cells, red) and interneurons ( $n=66$ cells, white). B, Occurrence of the three PGES isoforms in identified cell types. mPGES1 is not detected in any cell types. mPGES2 is more frequently observed in pyramidal neurons and interneurons than in astrocytes. CPGES is detected in the three cell types but more frequently in pyramidal cells than in astrocytes. ${ }^{*},{ }^{* *}$, and ${ }^{* * *}$ statistically significant with $p<0.05$, $p<0.01$, and $p<0.001$ respectively. $C$, Coexpression of prostanoid synthesizing enzymes in identified cell types. The occurrence of cells positive for an enzyme is proportional to the size of the box in a given cell type. Coexpression of PGES (green) and PGIS (blue) with COX-1 (top, purple) and with COX-2 (bottom, red) in astrocytes (S100 $\beta$ and/or GFAP-positive; left), pyramidal cells (vGluT1-positive; middle) and interneurons (GAD65- and/or 67-positive; right).

Table 7. Subthreshold properties of different neuronal populations

\begin{tabular}{|c|c|c|}
\hline & Pyramidal cells $(n=24)$ & Interneurons $(n=66)$ \\
\hline Resting potential, mV & $\begin{array}{l}-69.7 \pm 1.8 \\
U_{(24,66)}=286.5\end{array}$ & $\begin{array}{l}-59.8 \pm 0.8 \\
p=0.000001 \\
\text { Int }\end{array}$ \\
\hline Input resistance, $\mathrm{M} \Omega$ & $\begin{aligned} 277 & \pm 30 \\
U_{(24,66)} & =250\end{aligned}$ & $\begin{array}{l}526 \pm 29 \\
p=1.10^{-7} \\
\text { Int }\end{array}$ \\
\hline Time constant, ms & $\begin{array}{r}32.2 \pm 2.6 \\
U_{(24,66)}=728\end{array}$ & $\begin{array}{c}32.2 \pm 2.1 \\
p=0.564733\end{array}$ \\
\hline Membrane capacitance, pF & $\begin{array}{r}122.4 \pm 5.8 \\
U_{(24,66)}=133\end{array}$ & $\begin{array}{r}\quad 67.5 \pm 4.5 \\
p=2.10^{-11} \\
\text { Pyr. }\end{array}$ \\
\hline Sag index, \% & $\begin{array}{r}7.1 \pm 1.4 \\
U_{(24,66)}=669\end{array}$ & $\begin{array}{r}9.6 \pm 1.1 \\
p=0.265639\end{array}$ \\
\hline
\end{tabular}

Pyr, Pyramidal cells; Int, interneurons, $n$, number of cells; Mann-Whitney $U$ tests and corresponding exact $p$ values; $<<<$ indicates significantly smaller with $p<0.001 ; \mathrm{n}$.s., not statistically significant.

trast, our immunocytochemical (Fig. 4D) and scRT-PCR data showed that pyramidal neurons were the main cell type constitutively expressing COX-2 (astrocytes vs pyramidal cells, $p=$ 0.0026 , astrocytes vs interneurons, $p=0.7000$; pyramidal cells vs interneurons, $p=0.0046$; Fisher's exact tests; Fig. 7 A, C). Expression of at least one PGES was more frequent in neurons than in astrocytes (astrocytes vs pyramidal cells, $p=0.0001$; astrocytes vs interneurons, $p=0.0018$; pyramidal cells vs interneurons, $p=$ 0.1221; Fisher's exact tests; Fig. $7 A, C)$. cPGES was the main isoform in the three cell types and was most frequent in neurons and, particularly, in pyramidal cells (astrocytes vs pyramidal cells, $p=0.0009$; astrocytes vs interneurons, $p=0.0327$; pyramidal cells vs interneurons, $p=0.0894$; Fisher's exact tests; Fig. $7 B$ ). Expression mPGES2 was infrequent in neurons and very rare in astrocytes (astrocytes vs pyramidal cells, $p=0.0073$; astrocytes vs interneurons, $p=0.0041$; pyramidal cells vs interneurons, $p=$ 0.7904; Fisher's exact tests; Fig. $7 B$ ). PGIS was similarly rare in neurons and astrocytes (astrocytes vs pyramidal cells, $p=0.5415$; astrocytes vs interneurons, $p=0.2717$; pyramidal cells vs interneurons, $p=0.1000$; Fisher's exact tests; Fig. 7 A, C). Consistent with prostaglandin analysis (Fig. 2), these data indicate that perivascular astrocytes and cortical neurons are better equipped to produce $\mathrm{PgE}_{2}$ than $\mathrm{PgI}_{2}$. They also suggest that pyramidal neurons are the main source of $\mathrm{PgE}_{2}$-derived from COX-2 activity. Consistent with a neuronal origin of $\mathrm{PgE}_{2}$ in NVC, NMDAinduced vasodilations were dramatically reduced by blockade of action potentials with TTX $(5 \mu \mathrm{M}, n=8$ arterioles, maximal dilation $20.8 \pm 3.9 \%, p=0.00002, U_{(16,8)}=3$, magnitude $9.0 \pm$ $2.210^{3} . \% . s, p=0.00037, \mathrm{U}(16,8)=10$; Mann-Whitney U tests; Fig. 1) indicating that neuronal activity is required for these responses.

\section{Optogenetic stimulation of pyramidal cells induces COX-2-} dependent hyperemic responses

Similar to LDF, it has been reported that $95 \%$ of the laser-speckle contrast imaging signal comes from the top $700 \mu \mathrm{m}$ of tissue (Davis et al., 2014). To evaluate functionally the capability of pyramidal cells to release vasodilatory prostaglandins in vivo, we combined direct optogenetic stimulation of channelrhodopsin-2 (ChR-2)-expressing neurons with laser speckle contrast imaging of cerebral blood flow (Scott and Murphy, 2012). Similarly to rats, mice exhibit a COX-2-dependent NVC response to sensory stimulation (Niwa et al., 2000; Bakalova et al., 2002; Stefanovic et al., 2006; Lecrux et al., 2011). We therefore took advantage of available Cre driver lines to obtain an expression of ChR2 in pyramidal cells. Efficient expression of ChR-2 was obtained by crossing Emx1-Cre mice with Ai32 mice which permits a conditional expression of ChR2 and a robust photoexcitability of pyramidal cells (Madisen et al., 2012). Photoexcitation at $473 \mathrm{~nm}$ $(100 \mathrm{~Hz}, 5 \mathrm{~ms}, 3 \mathrm{~mW})$ of Emx1-Cre;Ai32 mice ( $n=5$ mice) 
Table 8. Action potential waveform properties of different neuronal populations

\begin{tabular}{|c|c|c|}
\hline & $\begin{array}{l}\text { Pyramidal cells } \\
(n=24)\end{array}$ & $\begin{array}{l}\text { Interneurons } \\
(n=66)\end{array}$ \\
\hline $1^{\text {st }}$ spike amplitude, $\mathrm{mV}$ & $\begin{array}{r}96.6 \pm 2.3 \\
U_{(24,66)}=476,5 \\
\text { Int }\end{array}$ & $\begin{array}{r}89.2 \pm 1.4 \\
p=0.00354\end{array}$ \\
\hline $2^{\text {nd }}$ spike amplitude, $\mathrm{mV}$ & $\begin{array}{r}95.0 \pm 2.3 \\
U_{(24,66)}=369 \\
\operatorname{lnt}\end{array}$ & $\begin{array}{r}85.2 \pm 1.5 \\
p=0.00007 \\
\text { Pyr }\end{array}$ \\
\hline $1^{\text {st }}$ spike duration, $\mathrm{ms}$ & $\begin{array}{r}1.3 \pm 0.1 \\
U_{(24,66)}=231 \\
\operatorname{lnt}\end{array}$ & $\begin{array}{r}0.7 \pm 0.1 \\
p=4.10^{-8} \\
\text { Pyr }\end{array}$ \\
\hline $2^{\text {nd }}$ spike duration, $\mathrm{ms}$ & $\begin{array}{r}1.3 \pm 0.1 \\
U_{(24,66)}=223 \\
\operatorname{lnt}\end{array}$ & $\begin{array}{r}0.7 \pm 0.0 \\
p=3.10^{-8} \\
\text { Pyr }\end{array}$ \\
\hline Amplitude reduction, $\%$ & $\begin{aligned} 1.6 & \pm 0.3 \\
U_{(24,66)} & =553\end{aligned}$ & $\begin{array}{r}4.4 \pm 0.8 \\
p=0.02888\end{array}$ \\
\hline Duration increase, $\%$ & $\begin{aligned} 0.7 & \pm 0.3 \\
U_{(24,66)} & =628\end{aligned}$ & $\begin{array}{r}0.8 \pm 1.9 \\
p=0.13646\end{array}$ \\
\hline $1^{\text {st }}$ spike, $1^{\text {st }}$ component AHP, mV & $\begin{array}{r}-5.9 \pm 0.6 \\
U_{(24,66)}=52 \\
\operatorname{lnt}\end{array}$ & $\begin{array}{l}-15.2 \pm 0.6 \\
p=8.10^{-16}\end{array}$ \\
\hline $1^{\text {st }}$ spike, $1^{\text {st }}$ AHP component latency, ms & $\begin{array}{r}7.0 \pm 0.6 \\
U_{(24,66)}=240 \\
\operatorname{lnt}\end{array}$ & $\begin{array}{l}\quad 3.8 \pm 0.2 \\
p=8.10^{-8} \\
\text { Pyr }\end{array}$ \\
\hline $1^{\text {st }}$ spike, $2^{\text {nd }}$ component AHP, mV & $\begin{array}{l}-12.9 \pm 0.6 \\
U_{(24,66)}=443\end{array}$ & $\begin{array}{r}-7.6 \pm 0.9 \\
p=0.00121\end{array}$ \\
\hline $1^{\text {st }}$ spike, $2^{\text {nd }}$ AHP component latency, ms & $\begin{array}{r}50.2 \pm 4.5 \\
U_{(24,66)}=155 \\
\operatorname{lnt}\end{array}$ & $\begin{array}{r}15.6 \pm 2.1 \\
p=1.10^{-10}\end{array}$ \\
\hline $1^{\text {st }}$ spike, ADP, mV & $\begin{aligned} 0.0 & \pm 0.0 \\
U_{(24,66)} & =444\end{aligned}$ & $\begin{array}{r}1.9 \pm 0.3 \\
p=0.00125\end{array}$ \\
\hline $1^{\text {st }}$ spike, ADP latency, ms & $\begin{aligned} 0.0 & \pm 0.0 \\
U_{(24,66)} & =444\end{aligned}$ & $\begin{array}{r}4.4 \pm 0.7 \\
p=0.00125\end{array}$ \\
\hline $2^{\text {nd }}$ spike, $1^{\text {st }}$ component AHP, mV & $\begin{array}{r}-6.5 \pm 0.7 \\
U_{(24,66)}=82 \\
\operatorname{lnt}\end{array}$ & $\begin{array}{l}-15.6 \pm 0.6 \\
p=6.10^{-14} \\
\text { Pyr }\end{array}$ \\
\hline $2^{\text {nd }}$ spike, $1^{\text {st }}$ AHP component latency, ms & $\begin{array}{r}9.3 \pm 1.6 \\
U_{(24,66)}=199 \\
\operatorname{lnt}\end{array}$ & $\begin{array}{r}\quad 3.8 \pm 0.3 \\
p=5.10^{-9} \\
\text { Pyr }\end{array}$ \\
\hline $2^{\text {nd }}$ spike, $2^{\text {nd }}$ component AHP, mV & $\begin{aligned} &-13.5 \pm 0.8 \\
& U_{(24,66)}=494 \\
& \text { Int }\end{aligned}$ & $\begin{array}{r}-9.5 \pm 0.9 \\
p=0.00608\end{array}$ \\
\hline $2^{\text {nd }}$ spike, $2^{\text {nd }}$ AHP component latency, ms & $\begin{array}{r}55.6 \pm 5.9 \\
U_{(24,66)}=172 \\
\operatorname{lnt}\end{array}$ & $\begin{array}{r}18.0 \pm 1.9 \\
p=6.10^{-10} \\
\text { Pyr }\end{array}$ \\
\hline $2^{\text {nd }}$ spike, ADP, mV & $\begin{aligned} & 0.0 \pm 0.0 \\
& U_{(24,66)}=432 \\
& \text { Pyr }\end{aligned}$ & $\begin{array}{r}1.9 \pm 0.3 \\
p=0.00082 \\
\text { Int }\end{array}$ \\
\hline $2^{\text {nd }}$ spike, ADP latency, ms & $\begin{aligned} 0.0 & \pm 0.0 \\
U_{(24,66)} & =432\end{aligned}$ & $\begin{array}{r}2.9 \pm 0.4 \\
p=0.00082 \\
\text { Int }\end{array}$ \\
\hline
\end{tabular}

Pyr, Pyramidal cells; Int, interneurons; $n$, number of cells; Mann-Whitney $U$ tests and corresponding exact $p$ values; $<,<<$ and $<<<$ indicate significantly smaller with $p<0.05,<0.01$, and $<0.001$, respectively; n.s., not statistically significant.

elicited a rapid and transient increase in cerebral blood flow (Fig. 8 ; magnitude $118.3 \pm 24.2 \%$.s, maximal change $27.7 \pm 3.5 \%$ ) that was not observed with Thy1-YFP mice that do not express ChR2 $\left(n=4\right.$ mice, magnitude $2.9 \pm 3.2 \% . s, p=0.01587, U_{(5,4)}=$ 0 ; maximal change $5.6 \pm 1.2 \%, p=0.01587, U_{(5,4)}=0$, MannWhitney $U$ tests; Fig. $8 B-D$ ). Consistent with the release of COX-
Table 9. Firing properties of different neuronal populations

\begin{tabular}{|c|c|c|}
\hline & Pyramidal cells $(n=24)$ & Interneurons $(n=66)$ \\
\hline Amplitude accommodation, $\mathrm{mV}$ & $\begin{aligned} 12.0 & \pm 1.3 \\
U_{(24,66)} & =242 \quad \\
& \quad \ln t<<\end{aligned}$ & $\begin{aligned} & 4.2 \pm 0.5 \\
& p=9.10^{-8} \\
&<\mathrm{Pyr}\end{aligned}$ \\
\hline Amplitude of early adaptation, $\mathrm{Hz}$ & $\begin{array}{r}95.1 \pm 7.8 \\
U_{(24,66)}=551\end{array}$ & $\begin{array}{r}77.5 \pm 5.4 \\
p=0.02753 \\
\text { Pyr }\end{array}$ \\
\hline Time constant of early adaptation, ms & $\begin{aligned} 15.4 & \pm 1.5 \\
U_{(24,66)} & =398 \quad \\
& \text { Pyr }<<\end{aligned}$ & $\begin{array}{l}\quad 25.2 \pm 2.1 \\
p=0.00023 \\
<\text { Int }\end{array}$ \\
\hline Maximal steady-state frequency, $\mathrm{Hz}$ & $\begin{aligned} 45.6 & \pm 2.8 \\
U_{(24,66)} & =315 \quad \\
& \text { Pyr }<<\end{aligned}$ & $\begin{array}{l}\quad 92.0 \pm 7.5 \\
p=0.00001 \\
<\text { Int }\end{array}$ \\
\hline Late adaptation, $\mathrm{Hz} / \mathrm{s}$ & $\begin{array}{l}-24.6 \pm 1.9 \\
U_{(24,66)}=633\end{array}$ & $\begin{array}{l}-189.3 \pm 151.0 \\
p=0.14899\end{array}$ \\
\hline
\end{tabular}

Pyr, Pyramidal cells; Int, interneurons; $n$, number of cells; Mann-Whitney $U$ tests and corresponding exact $p$ values; $<$ and $<<<$ indicate significantly smaller with $p<0.05$ and $<0.001$, respectively; n.s., not statistically significant.

Table 10. 0ccurrence of molecular markers in different neuronal populations

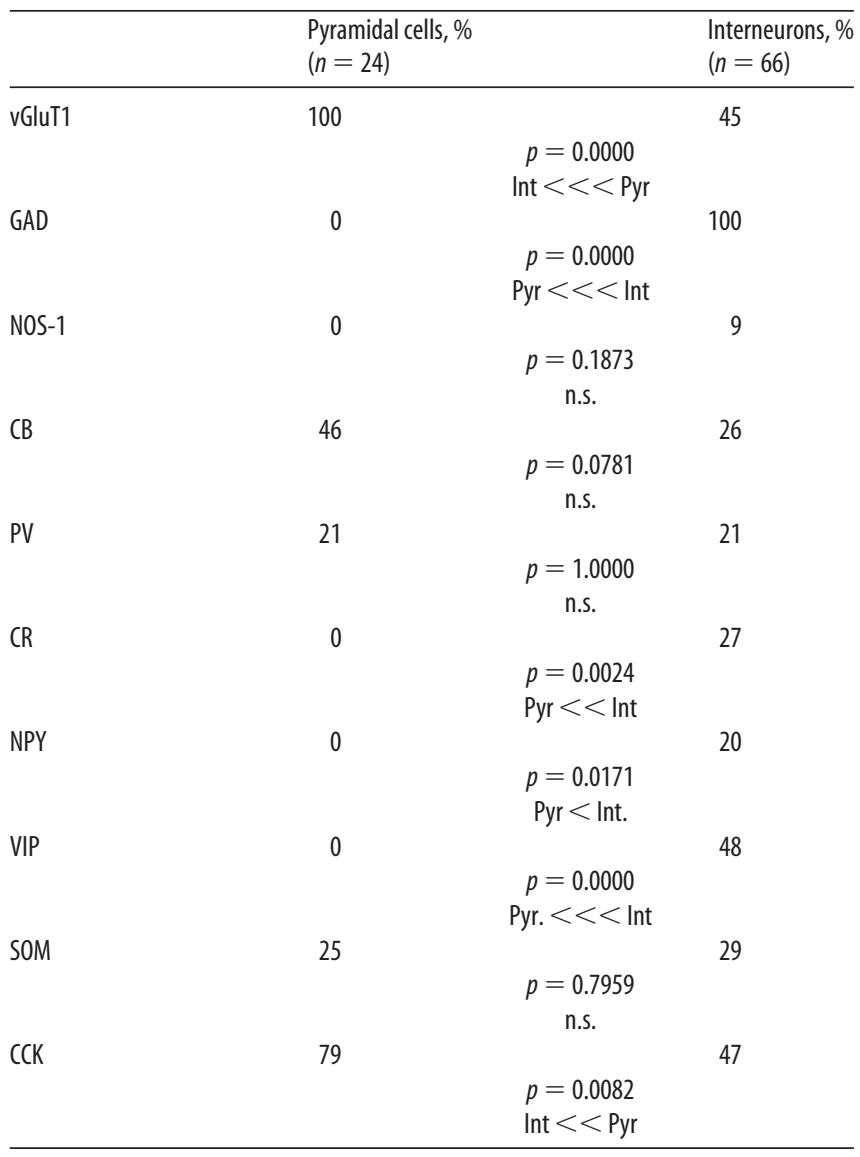

Pyr, Pyramidal cells; Int, interneurons; $n$, number of cells; Fisher's exact test $p$ values; $<,<<$ and $<<<$ indicate significantly smaller with $p<0.05,<0.01$, and $<0.001$, respectively; n.S., not statistically significan.

2-derived $\mathrm{PgE}_{2}$, laser speckle contrast changes evoked by photoexcitation of Emx1-Cre;Ai32 pyramidal cells were reduced by application of the COX-2 inhibitor NS $398(100 \mu \mathrm{M}$, Magnitude $55.9 \pm 12.4 \% . s, p=0.0226, t_{(4)}=3.6064$, paired $t$ test, maximal change $16.0 \pm 3.7 \%, p=0.0226, t_{(4)}=3.6080$, paired $t$ test; Fig. $8 B-D$ ). These optogenetic results show that direct activation of pyramidal cells is sufficient to release COX-2-derived vasodilatory prostaglandins. 
A

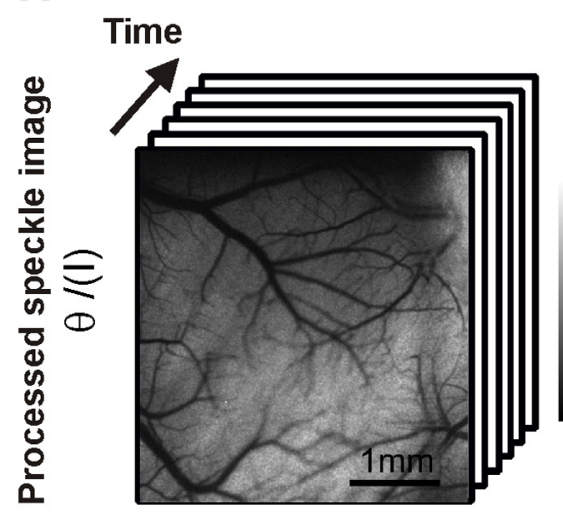

B

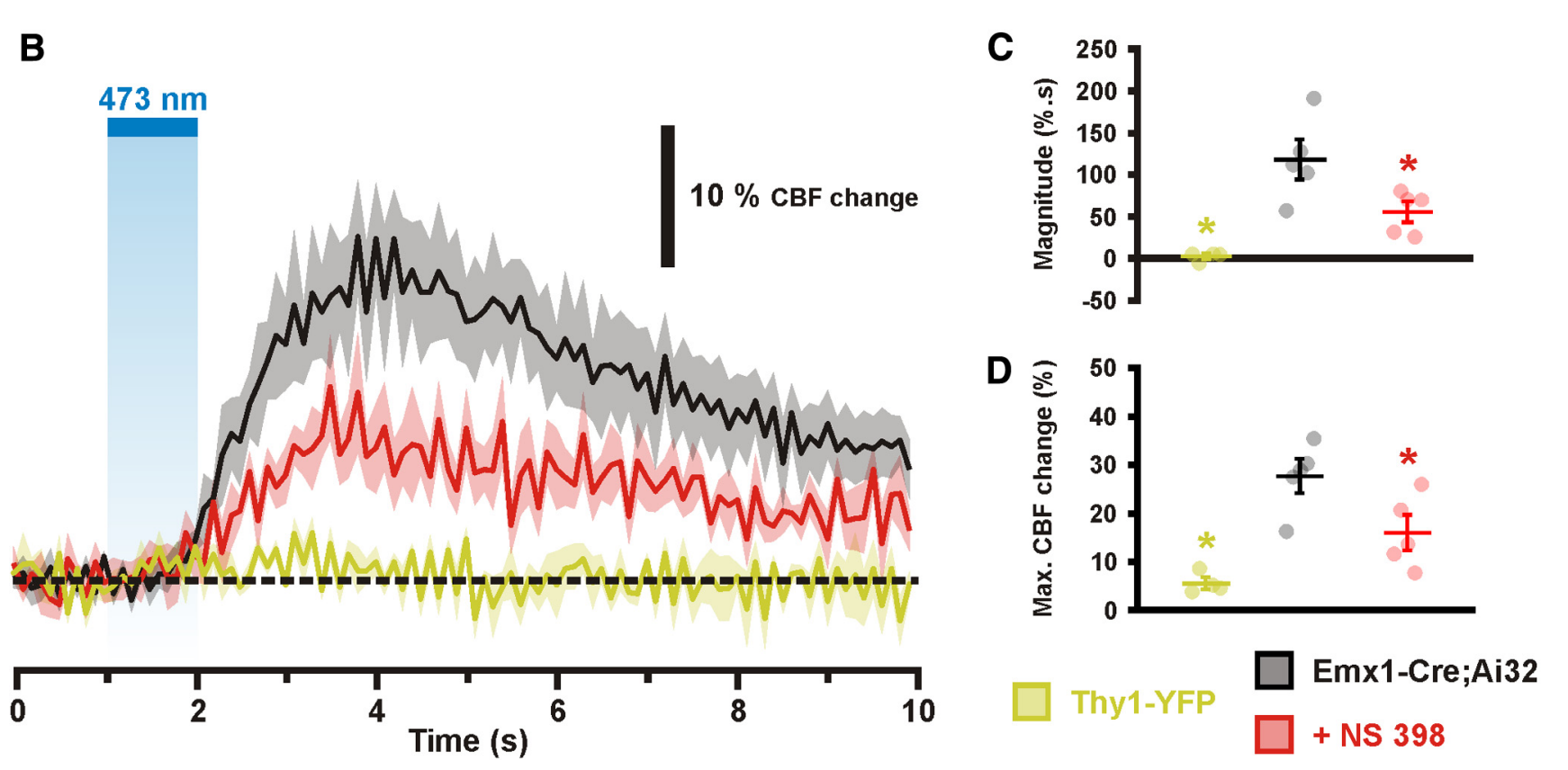

$100 \mathrm{~Hz}, 5 \mathrm{~ms}, 3 \mathrm{~mW}$
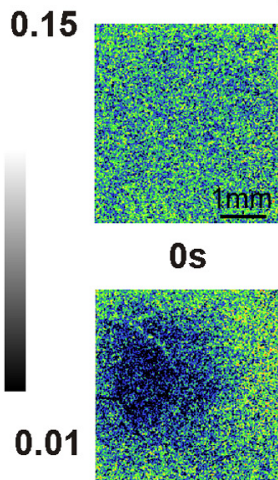

Os

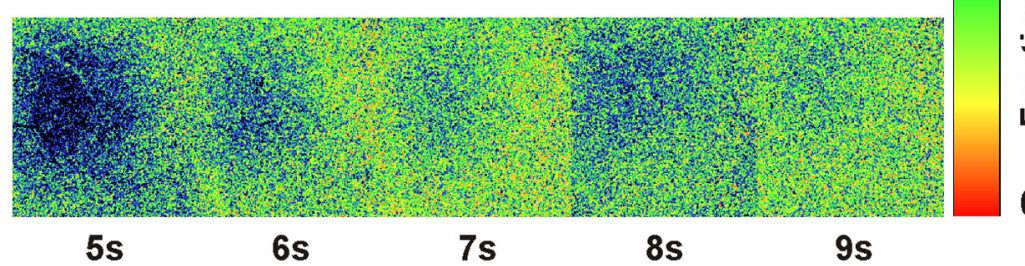

$-0.1$

Figure 8. Optogenetic stimulations of pyramidal cells evoke COX-2-dependent hyperemic responses. $\boldsymbol{A}$, Variance filtered speckle contrast image. Darker tones represent higher velocity blood flow. Montage of fractional change in speckle contrast images from cortical optogenetic stimulation of an Emx1-Cre;Ai32 mouse. $B, 0$ ptogenetically evoked increases in blood flow, the scaled inverse square of speckle contrast, before (black trace) and after application of NS 398 (red trace; $n=5$ mice). Blue light excitation ( $473 \mathrm{~nm}$ ) in Thy1-YFP mice (yellow; $n=4$ mice) does note evoke increase in blood flow. The SEM envelopes the mean traces. $\boldsymbol{C}, \boldsymbol{D}$, Effects of photostimulation on magnitude $(\boldsymbol{C})$ and maximal changes $(\boldsymbol{D})$ of blood flow in Thy1-YFP and Emx1-Cre;Ai32 mice before and after NS 398 application. Dots represent individual neurovascular responses. Horizontal bars and error bars correspond to the mean \pm SEM. *Statistically different from Emx1-Cre;Ai32 mice under baseline condition with $p<0.05$.

\section{Discussion}

Here we deciphered the molecular and cellular mechanisms responsible for the biosynthesis and activity of vasodilatory prostaglandins involved in NVC (Fig. 9). We identified in slices the rate-limiting enzyme involved in this pathway by showing that COX-2, but also to a lesser extent COX-1, metabolites mediate NMDA-induced vasodilations. Further, we identified $\mathrm{PgE}_{2}$ as the main vasodilatory prostaglandins by demonstrating ex vivo and in vivo the implication of its EP2 and EP4 receptors and by showing its release ex vivo using LC-ESI-MS/MS. We found that pyramidal cells are the main cell type equipped for $\mathrm{PgE}_{2}$ synthesis derived from COX-2 activity. Moreover we showed that increased activity of these neurons through direct optogenetic stimulation evoked COX-2-dependent NVC responses, hence demonstrating a key role for $\mathrm{PgE}_{2}$-derived from pyramidal cells in NVC responses.
Cellular distribution of $\mathrm{PgE}_{2}$ and $\mathrm{PgI}_{2}$ synthesizing enzymes Our data showing COX-1 expression in various cell types are supported by previous observations demonstrating its localization in microglia, astrocytes, neurons and endothelial cells (Takano et al., 2006; Cahoy et al., 2008; Gordon et al., 2008; Tang and Vanhoutte, 2008; Tanaka et al., 2009; Anrather et al., 2011; Lecrux et al., 2011). In contrast, we observed by immunohistochemistry and scRT-PCR that COX-2 is largely restricted to pyramidal neurons, rarely in astrocytes and interneurons, and virtually absent in microglial cells and the vascular bed (Yamagata et al., 1993; Breder et al., 1995; Kaufmann et al., 1996; Wang et al., 2005; Takano et al., 2006; Cahoy et al., 2008; Gordon et al., 2008; Anrather et al., 2011; Lecrux et al., 2011). Regarding the terminal $\mathrm{PgE}_{2}$ synthesizing enzymes, cPGES was observed in all cell types investigated (Vazquez-Tello et al., 2004; Sang et al., 2005; Cahoy et al., 2008), mPGES2 was essentially detected in neurons (Sang et 
al., 2005; Cahoy et al., 2008), whereas mPGES1 was virtually absent from neurons and astrocytes (Ikeda-Matsuo et al., 2006; Cahoy et al., 2008). We also confirmed a rather infrequent PGIS expression (Mehl et al., 1999; Cahoy et al., 2008). Importantly, we disclosed that COX-2positive pyramidal cells systematically express a cPGES and/or mPGES2 to a lesser extent. This indicates that under homeostatic conditions COX-2-derived $\mathrm{PgE}_{2}$ is essentially produced by pyramidal cells.

\section{Origins of vasodilatory prostaglandins in NVC}

Perivascular astrocytes can release COX1-, but not COX-2-derived, vasodilatory prostaglandins following activation of group I metabotropic glutamate receptors (Zonta et al., 2003; Takano et al., 2006; Gordon et al., 2008). However, the recruitment of this pathway during sensory stimulation is unlikely because pharmacological and genetic evidence showed that such stimuli elicit COX-2, but not COX-1,-dependent hyperemic responses (Niwa et al., 2000, 2001; Bakalova et al., 2002; Stefanovic et al., 2006; Lecrux et al., 2011). Furthermore, the recruitment of astrocytes by group I metabotropic glutamate receptors has been recently questioned (Calcinaghi et al., 2011; Nizar et al., 2013; Sun et al., 2013; Bonder and McCarthy, 2014; Jego et al., 2014). This suggests that under normal conditions sensory stimulations do not substantially recruit vasodilatory prostaglandins produced by astrocytes.

We found that NMDA-induced vasodilations were almost completely abolished by COX-2 inhibition, suggesting that the NMDA-dependent fraction of the NVC response is essentially mediated by vasodilatory prostaglandins. Our results indicating that COX-2-derived $\mathrm{PgE}_{2}$ released during sensory stimulation has a pyramidal origin are supported further by optogenetic observations showing that the selective photostimulation of CaMKII $\alpha$ pyramidal cells, which extensively coexpress COX-2 (Kaufmann et al., 1996), evoked a hemodynamic response (J. H. Lee et al., 2010; Ji et al., 2012). In addition, the NVC responses induced by the photostimulation of pyramidal neurons, but not by sensory stimulation, are virtually insensitive to ionotropic glutamate receptors blockade (Scott and Murphy, 2012). This further points to release of vasodilatory messengers by pyramidal cells. Since the NVC involves numerous vasoactive messengers (Iadecola, 2004; Leithner et al., 2010; Liu et al., 2012), it is likely that the optogenetic photostimulation of pyramidal cells recruits indirectly other vasoactive messengers. Consistently, a substantial fraction of the NVC response to sensory stimulation is insensitive to COX-2 inhibition (Niwa et al., 2000; Bakalova et al., 2002; Stefanovic et al., 2006; Lecrux et al., 2011) and $\mathrm{PgE}_{2}$ receptor antagonism (present study). Interestingly, COX-2 has been described in dendrites, spines or axon terminals (Kaufmann et al., 1996; Wang et al., 2005), suggesting that pyramidal cells can remotely release $\mathrm{PgE}_{2}$.

We found that the initial phase of NMDA-induced vasodilations was also COX-1-dependent. The cellular origin of COX-1-derived prostaglandins released by NMDA remains undetermined given the large cellular distribution of COX-1 (see above) and the widespread expression of NMDA receptors in various neuronal types (Cauli et al., 2000), but also in some astrocytes, microglial and endothelial cells (Lalo et al., 2006; Kaindl et al., 2012; LeMaistre et al., 2012). Microglia, a major cell type expressing COX-1, can release $\mathrm{PgE}_{2}$ upon NMDA stimulation, but secondary to neuronal ATP release (Anrather et al., 2011) making unlikely their contribution to the early NVC response. The expression of COX-1 in neurons and astrocytes suggests that these cell types might be responsible for the early NVC response. Finally, given that endothelial cells play a key role in fast hemodynamics (Chen et al., 2014), they might also contribute to the early NVC response.

\section{Release of prostaglandins}

Consistent with in vivo data (Lazarewicz and Salińska, 1995; Pepicelli et al., 2005; Anrather et al., 2011) we observed a COX-1 and COX-2-dependent release of $\mathrm{PgE}_{2}$ and 6-keto $\mathrm{PgF}_{1 \alpha}$. The level of $\mathrm{PgE}_{2}$ release by NMDA is approximately one-half that found with mGluR1/5 agonists (Gordon et al., 2008), suggesting that they are more efficient than NMDA at inducing $\mathrm{PgE}_{2}$ release. This is consistent with widespread expression of mGluR1/5 in astrocytes and neurons (Porter and McCarthy, 1996; Cauli et al., 2000). However, number of slices and duration of incubation were not described (Gordon et al., 2008) making a direct comparison difficult. Furthermore, due to cross-reactivity among the different prostaglandins, the content in $\mathrm{PgE}_{2}$ may have been overestimated by using immunoassay (Schmidt et al., 2005). Interestingly, in line with in vivo observations (Lazarewicz et al., 2000), using LC-ESI-MS/MS we found that up to $396 \pm 141 \mathrm{pg} / \mathrm{ml} \mathrm{PgD}_{2}$ was released by NMDA, a prostaglandin structurally similar to $\mathrm{PgE}_{2}$.

The dynamics of the NMDA-dependent $\mathrm{PgE}_{2}$ and 6-keto $\mathrm{PgF}_{1 \alpha}$ (Fig. 2) are overall compatible with the kinetics NMDAinduced vasodilations (Fig. 1). However a direct comparison is difficult given the different mode of NMDA delivery and washout between supernatant analysis and vascular reactivity (Mishra et 
al., 2014). The sustained vasodilation after NMDA washout is reminiscent of an intracellular $\mathrm{Ca}^{2+}$ increase after a prolonged exposure of NMDA, involving an initial increase via NMDA receptors followed by a secondary activation of other $\mathrm{Ca}^{2+}$ permeable channels including transient receptor potential channels (Olah et al., 2009) and/or voltage-gated $\mathrm{Ca}^{2+}$ channels (Oda et al., 2014). Recruitment of extrasynaptic NMDA receptors are likely to be responsible for this secondary $\mathrm{Ca}^{2+}$ increase (Oda et al., 2014) and overproduction of $\mathrm{PgE}_{2}$ (Stark and Bazan, 2011). Whether or not these different initial entry points are specifically coupled with COX-1 and/or COX-2 remains to be determined.

\section{Prostaglandin receptors in NVC}

The prostaglandin receptors EP2, EP4, and IP are expressed in cerebrovascular smooth muscle cells and pericytes (Myren et al., 2010, 2011; Dabertrand et al., 2013; Hall et al., 2014). We observed an impairment of the NVC responses by the EP2 and EP4 antagonists both ex vivo and in vivo. These data suggesting an involvement of $\mathrm{PgE}_{2}$ are consistent with recent observations showing a recruitment of EP4 receptors in cerebral vasodilation evoked by glutamate (Hall et al., 2014). Antagonism of both EP2 and EP4 receptors reduced the maximal amplitude of NMDAinduced vasodilation, but their magnitude were only impaired by the EP2 antagonist, indicating that EP2 receptors may have a longer lasting vasodilatory effect than EP4 receptors. This is consistent with the reported agonist-induced internalization of EP4 but not EP2 receptor (Desai et al., 2000). This further suggests that $\mathrm{EP} 2$ receptor would be the major vasodilatory $\mathrm{PgE}_{2}$ receptor activated during a sustained hyperemic response. Because 14,15EET can induce vasodilation by acting on EP2 receptors (Yang et al., 2010), the AH 6809-sensitive vasodilation could be also explained by the release of 14,15-EET from astrocytes (Alkayed et al., 1996, 1997; Fig. 9). Although the IP antagonist impaired NMDA-induced vasodilations in slices, it did not alter the hyperemic response to sensory stimulation. This difference between ex vivo and in vivo NVC responses is probably because bath application of NMDA recruits more massively NMDA receptors than sensory stimuli, resulting in enhanced $\mathrm{PgI}_{2}$ biosynthesis and release. In addition, the levels of 6-keto $\mathrm{PgF}_{1 \alpha}$ released in slices are very low; it is therefore likely that the production of $\mathrm{PgI}_{2}$ induced by sensory stimulation in vivo is negligible.

\section{Conclusion}

Using different multidisciplinary approaches we demonstrate that pyramidal cells produce and release COX-2-derived $\mathrm{PgE}_{2}$ inducing vasodilation and functional hyperemia via activation of EP2 and EP4 receptors. So far most studies focused almost exclusively on the role of astrocytes in NVC (Attwell et al., 2010) thereby overlooking the possibility of a direct neurogenic control. Our finding emphasizing the importance of neurons provides important insights in the field of NVC and will have consequences on the interpretation of functional imaging based on hemodynamic signals widely used to map neuronal activity in health and disease.

\section{References}

Alkayed NJ, Narayanan J, Gebremedhin D, Medhora M, Roman RJ, Harder DR (1996) Molecular characterization of an arachidonic acid epoxygenase in rat brain astrocytes. Stroke 27:971-979. CrossRef Medline

Alkayed NJ, Birks EK, Narayanan J, Petrie KA, Kohler-Cabot AE, Harder DR (1997) Role of P-450 arachidonic acid epoxygenase in the response of cerebral blood flow to glutamate in rats. Stroke 28:1066-1072. CrossRef Medline

Andjelic S, Gallopin T, Cauli B, Hill EL, Roux L, Badr S, Hu E, Tamás G,
Lambolez B (2009) Glutamatergic nonpyramidal neurons from neocortical layer VI and their comparison with pyramidal and spiny stellate neurons. J Neurophysiol 101:641-654. CrossRef Medline

Andrew RD, Adams JR, Polischuk TM (1996) Imaging NMDA- and kainate-induced intrinsic optical signals from the hippocampal slice. J Neurophysiol 76:2707-2717. Medline

Anrather J, Gallo EF, Kawano T, Orio M, Abe T, Gooden C, Zhou P, Iadecola C (2011) Purinergic signaling induces cyclooxygenase-1-dependent prostanoid synthesis in microglia: roles in the outcome of excitotoxic brain injury. PLoS One 6:e25916. CrossRef Medline

Ascoli GA, Alonso-Nanclares L, Anderson SA, Barrionuevo G, BenavidesPiccione R, Burkhalter A, Buzsáki G, Cauli B, Defelipe J, Fairén A, Feldmeyer D, Fishell G, Fregnac Y, Freund TF, Gardner D, Gardner EP, Goldberg JH, Helmstaedter M, Hestrin S, Karube F, et al. (2008) Petilla terminology: nomenclature of features of GABAergic interneurons of the cerebral cortex. Nat Rev Neurosci 9:557-568. CrossRef Medline

Attwell D, Buchan AM, Charpak S, Lauritzen M, Macvicar BA, Newman EA (2010) Glial and neuronal control of brain blood flow. Nature 468:232243. CrossRef Medline

Bakalova R, Matsuura T, Kanno I (2002) The cyclooxygenase inhibitors indomethacin and Rofecoxib reduce regional cerebral blood flow evoked by somatosensory stimulation in rats. Exp Biol Med (Maywood) 227:465473. Medline

Blanco VM, Stern JE, Filosa JA (2008) Tone-dependent vascular responses to astrocyte-derived signals. Am J Physiol Heart Circ Physiol 294:H2855H2863. CrossRef Medline

Bley KR, Bhattacharya A, Daniels DV, Gever J, Jahangir A, O'Yang C, Smith S, Srinivasan D, Ford AP, Jett MF (2006) RO1138452 and RO3244794: characterization of structurally distinct, potent and selective IP (prostacyclin) receptor antagonists. Br J Pharmacol 147:335-345. Medline

Bochet P, Audinat E, Lambolez B, Crépel F, Rossier J, Iino M, Tsuzuki K, Ozawa S (1994) Subunit composition at the single-cell level explains functional properties of a glutamate-gated channel. Neuron 12:383-388. CrossRef Medline

Boie Y, Stocco R, Sawyer N, Slipetz DM, Ungrin MD, Neuschäfer-Rube F, Püschel GP, Metters KM, Abramovitz M (1997) Molecular cloning and characterization of the four rat prostaglandin E2 prostanoid receptor subtypes. Eur J Pharmacol 340:227-241. CrossRef Medline

Bonder DE, McCarthy KD (2014) Astrocytic Gq-GPCR-linked IP3Rdependent $\mathrm{Ca} 2+$ signaling does not mediate neurovascular coupling in mouse visual cortex in vivo. J Neurosci 34:13139-13150. CrossRef Medline

Breder CD, Dewitt D, Kraig RP (1995) Characterization of inducible cyclooxygenase in rat brain. J Comp Neurol 355:296-315. CrossRef Medline

Briers JD (2001) Laser Doppler, speckle and related techniques for blood perfusion mapping and imaging. Physiol Meas 22:R35-R66. CrossRef Medline

Cahoy JD, Emery B, Kaushal A, Foo LC, Zamanian JL, Christopherson KS, Xing Y, Lubischer JL, Krieg PA, Krupenko SA, Thompson WJ, Barres BA (2008) A transcriptome database for astrocytes, neurons, and oligodendrocytes: a new resource for understanding brain development and function. J Neurosci 28:264-278. CrossRef Medline

Calcinaghi N, Jolivet R, Wyss MT, Ametamey SM, Gasparini F, Buck A, Weber B (2011) Metabotropic glutamate receptor mGluR5 is not involved in the early hemodynamic response. J Cereb Blood Flow Metab 31:e1-10. CrossRef Medline

Cauli B, Hamel E (2010) Revisiting the role of neurons in neurovascular coupling. Front Neuroenergetics 2:9. CrossRef Medline

Cauli B, Audinat E, Lambolez B, Angulo MC, Ropert N, Tsuzuki K, Hestrin S, Rossier J (1997) Molecular and physiological diversity of cortical nonpyramidal cells. J Neurosci 17:3894-3906. Medline

Cauli B, Porter JT, Tsuzuki K, Lambolez B, Rossier J, Quenet B, Audinat E (2000) Classification of fusiform neocortical interneurons based on unsupervised clustering. Proc Natl Acad Sci U S A 97:6144-6149. CrossRef Medline

Cauli B, Tong XK, Rancillac A, Serluca N, Lambolez B, Rossier J, Hamel E (2004) Cortical GABA interneurons in neurovascular coupling: relays for subcortical vasoactive pathways. J Neurosci 24:8940-8949. CrossRef Medline

Chen BR, Kozberg MG, Bouchard MB, Shaik MA, Hillman EM (2014) A critical role for the vascular endothelium in functional neurovascular coupling in the brain. J Am Heart Assoc 3:e000787. CrossRef Medline 
Cheng H, Duong TQ (2007) Simplified laser-speckle-imaging analysis method and its application to retinal blood flow imaging. Opt Lett 32: 2188-2190. CrossRef Medline

Dabertrand F, Hannah RM, Pearson JM, Hill-Eubanks DC, Brayden JE, Nelson MT (2013) Prostaglandin E(2), a postulated astrocyte-derived neurovascular coupling agent, constricts rather than dilates parenchymal arterioles. J Cereb Blood Flow Metab 33:479-482. CrossRef Medline

Damm J, Luheshi GN, Gerstberger R, Roth J, Rummel C (2011) Spatiotemporal nuclear factor interleukin-6 expression in the rat brain during lipopolysaccharide-induced fever is linked to sustained hypothalamic inflammatory target gene induction. J Comp Neurol 519:480-505. CrossRef Medline

Davis MA, Kazmi SM, Dunn AK (2014) Imaging depth and multiple scattering in laser speckle contrast imaging. J Biomed Opt 19:086001. CrossRef Medline

Davis RJ, Murdoch CE, Ali M, Purbrick S, Ravid R, Baxter GS, Tilford N, Sheldrick RL, Clark KL, Coleman RA (2004) EP4 prostanoid receptormediated vasodilatation of human middle cerebral arteries. Br J Pharmacol 141:580-585. CrossRef Medline

Desai S, April H, Nwaneshiudu C, Ashby B (2000) Comparison of agonistinduced internalization of the human EP2 and EP4 prostaglandin receptors: role of the carboxyl terminus in EP4 receptor sequestration. Mol Pharmacol 58:1279-1286. CrossRef Medline

Dodt HU, Zieglgänsberger W (1998) Visualization of neuronal form and function in brain slices by infrared videomicroscopy. Histochem J 30: 141-152. CrossRef Medline

Feng G, Mellor RH, Bernstein M, Keller-Peck C, Nguyen QT, Wallace M, Nerbonne JM, Lichtman JW, Sanes JR (2000) Imaging neuronal subsets in transgenic mice expressing multiple spectral variants of GFP. Neuron 28:41-51. CrossRef Medline

Fergus A, Lee KS (1997) Regulation of cerebral microvessels by glutamatergic mechanisms. Brain Res 754:35-45. CrossRef Medline

Filosa JA, Morrison HW, Iddings JA, Du W, Kim KJ (2015) Beyond neurovascular coupling, role of astrocytes in the regulation of vascular tone. Neuroscience. Advance online publication. Retrieved April 3, 2015. CrossRef Medline

Fox PT, Raichle ME, Mintun MA, Dence C (1988) Nonoxidative glucose consumption during focal physiologic neural activity. Science 241:462464. CrossRef Medline

Fredriksson I, Larsson M, Strömberg T (2009) Measurement depth and volume in laser Doppler flowmetry. Microvasc Res 78:4-13. CrossRef Medline

Funk CD (2001) Prostaglandins and leukotrienes: advances in eicosanoid biology. Science 294:1871-1875. CrossRef Medline

Gallopin T, Geoffroy H, Rossier J, Lambolez B (2006) Cortical sources of CRF, NKB, and CCK and their effects on pyramidal cells in the neocortex. Cereb Cortex 16:1440-1452. CrossRef Medline

Girouard H, Bonev AD, Hannah RM, Meredith A, Aldrich RW, Nelson MT (2010) Astrocytic endfoot $\mathrm{Ca} 2+$ and BK channels determine both arteriolar dilation and constriction. Proc Natl Acad Sci U S A 107:3811-3816. CrossRef Medline

Gordon GR, Choi HB, Rungta RL, Ellis-Davies GC, MacVicar BA (2008) Brain metabolism dictates the polarity of astrocyte control over arterioles. Nature 456:745-749. CrossRef Medline

Gorski JA, Talley T, Qiu M, Puelles L, Rubenstein JL, Jones KR (2002) Cortical excitatory neurons and glia, but not GABAergic neurons, are produced in the Emx1-expressing lineage. J Neurosci 22:6309-6314. Medline

Gsell W, Burke M, Wiedermann D, Bonvento G, Silva AC, Dauphin F, Bührle C, Hoehn M, Schwindt W (2006) Differential effects of NMDA and AMPA glutamate receptors on functional magnetic resonance imaging signals and evoked neuronal activity during forepaw stimulation of the rat. J Neurosci 26:8409-8416. CrossRef Medline

Hall CN, Reynell C, Gesslein B, Hamilton NB, Mishra A, Sutherland BA, O'Farrell FM, Buchan AM, Lauritzen M, Attwell D (2014) Capillary pericytes regulate cerebral blood flow in health and disease. Nature 508: 55-60. CrossRef Medline

Harb R, Whiteus C, Freitas C, Grutzendler J (2013) In vivo imaging of cerebral microvascular plasticity from birth to death. J Cereb Blood Flow Metab 33:146-156. CrossRef Medline

Horky LL, Galimi F, Gage FH, Horner PJ (2006) Fate of endogenous stem/ progenitor cells following spinal cord injury. J Comp Neurol 498:525538. CrossRef Medline
Houades V, Koulakoff A, Ezan P, Seif I, Giaume C (2008) Gap junctionmediated astrocytic networks in the mouse barrel cortex. J Neurosci 28: 5207-5217. CrossRef Medline

Iadecola C (2004) Neurovascular regulation in the normal brain and in Alzheimer's disease. Nat Rev Neurosci 5:347-360. CrossRef Medline

Iadecola C, Nedergaard M (2007) Glial regulation of the cerebral microvasculature. Nat Neurosci 10:1369-1376. CrossRef Medline

Ikeda-Matsuo Y, Ota A, Fukada T, Uematsu S, Akira S, Sasaki Y (2006) Microsomal prostaglandin E synthase-1 is a critical factor of strokereperfusion injury. Proc Natl Acad Sci U S A 103:11790-11795. CrossRef Medline

Jego P, Pacheco-Torres J, Araque A, Canals S (2014) Functional MRI in mice lacking IP-dependent calcium signaling in astrocytes. J Cereb Blood Flow Metab 34:1599-1603. CrossRef Medline

Ji L, Zhou J, Zafar R, Kantorovich S, Jiang R, Carney PR, Jiang H (2012) Cortical neurovascular coupling driven by stimulation of channelrhodopsin-2. PLoS One 7:e46607. CrossRef Medline

Kaindl AM, Degos V, Peineau S, Gouadon E, Chhor V, Loron G, Le Charpentier T, Josserand J, Ali C, Vivien D, Collingridge GL, Lombet A, Issa L, Rene F, Loeffler JP, Kavelaars A, Verney C, Mantz J, Gressens P (2012) Activation of microglial $N$-methyl-D-aspartate receptors triggers inflammation and neuronal cell death in the developing and mature brain. Ann Neurol 72:536-549. CrossRef Medline

Karagiannis A, Gallopin T, Dávid C, Battaglia D, Geoffroy H, Rossier J, Hillman EM, Staiger JF, Cauli B (2009) Classification of NPY-expressing neocortical interneurons. J Neurosci 29:3642-3659. CrossRef Medline

Kaufmann WE, Worley PF, Pegg J, Bremer M, Isakson P (1996) COX-2, a synaptically induced enzyme, is expressed by excitatory neurons at postsynaptic sites in rat cerebral cortex. Proc Natl Acad Sci U S A 93:23172321. CrossRef Medline

Lacoste B, Comin CH, Ben-Zvi A, Kaeser PS, Xu X, Costa LF, Gu C (2014) Sensory-related neural activity regulates the structure of vascular networks in the cerebral cortex. Neuron 83:1117-1130. CrossRef Medline

Lalo U, Pankratov Y, Kirchhoff F, North RA, Verkhratsky A (2006) NMDA receptors mediate neuron-to-glia signaling in mouse cortical astrocytes. J Neurosci 26:2673-2683. CrossRef Medline

Lambolez B, Audinat E, Bochet P, Crépel F, Rossier J (1992) AMPA receptor subunits expressed by single Purkinje cells. Neuron 9:247-258. CrossRef Medline

Lauritzen M (2005) Reading vascular changes in brain imaging: is dendritic calcium the key? Nat Rev Neurosci 6:77-85. CrossRef Medline

Lazarewicz JW, Salińska E (1995) $N$-methyl-D-aspartate-evoked release of cyclo-oxygenase products in rabbit hippocampus: an in vivo microdialysis study. J Neurosci Res 40:660-666. CrossRef Medline

Lazarewicz JW, Salinska E, Stafiej A, Ziembowicz A, Zieminska E (2000) NMDA receptors and nitric oxide regulate prostaglandin D2 synthesis in the rabbit hippocampus in vivo. Acta Neurobiol Exp (Wars) 60:427-435. Medline

Lecrux C, Toussay X, Kocharyan A, Fernandes P, Neupane S, Lévesque M, Plaisier F, Shmuel A, Cauli B, Hamel E (2011) Pyramidal neurons are "neurogenic hubs" in the neurovascular coupling response to whisker stimulation. J Neurosci 31:9836-9847. CrossRef Medline

Lecrux C, Kocharyan A, Sandoe CH, Tong XK, Hamel E (2012) Pyramidal cells and cytochrome P450 epoxygenase products in the neurovascular coupling response to basal forebrain cholinergic input. J Cereb Blood Flow Metab 32:896-906. CrossRef Medline

Lee JH, Durand R, Gradinaru V, Zhang F, Goshen I, Kim DS, Fenno LE, Ramakrishnan C, Deisseroth K (2010) Global and local fMRI signals driven by neurons defined optogenetically by type and wiring. Nature 465:788-792. CrossRef Medline

Lee S, Hjerling-Leffler J, Zagha E, Fishell G, Rudy B (2010) The largest group of superficial neocortical GABAergic interneurons expresses ionotropic serotonin receptors. J Neurosci 30:16796-16808. CrossRef Medline

Leithner C, Royl G, Offenhauser N, Füchtemeier M, Kohl-Bareis M, Villringer A, Dirnagl U, Lindauer U (2010) Pharmacological uncoupling of activation induced increases in CBF and CMRO(2). J Cereb Blood Flow Metab 30:311-322. CrossRef Medline

LeMaistre JL, Sanders SA, Stobart MJ, Lu L, Knox JD, Anderson HD, Anderson CM (2012) Coactivation of NMDA receptors by glutamate and D-serine induces dilation of isolated middle cerebral arteries. J Cereb Blood Flow Metab 32:537-547. CrossRef Medline

Liu X, Li C, Falck JR, Harder DR, Koehler RC (2012) Relative contribution 
of cyclooxygenases, epoxyeicosatrienoic acids, and $\mathrm{pH}$ to the cerebral blood flow response to vibrissal stimulation. Am J Physiol Heart Circ Physiol 302:H1075-H1085. CrossRef Medline

Lloyd-Burton S, Roskams AJ (2012) SPARC-like 1 (SC1) is a diversely expressed and developmentally regulated matricellular protein that does not compensate for the absence of SPARC in the CNS. J Comp Neurol 520:2575-2590. CrossRef Medline

Logothetis NK, Pauls J, Augath M, Trinath T, Oeltermann A (2001) Neurophysiological investigation of the basis of the fMRI signal. Nature 412: 150-157. CrossRef Medline

Lora M, Denault JB, Leduc R, de Brum-Fernandes AJ (1998) Systematic pharmacological approach to the characterization of NSAIDs. Prostaglandins Leukot Essent Fatty Acids 59:55-62. CrossRef Medline

Lovick TA, Brown LA, Key BJ (1999) Neurovascular relationships in hippocampal slices: physiological and anatomical studies of mechanisms underlying flow-metabolism coupling in intraparenchymal microvessels. Neuroscience 92:47-60. CrossRef Medline

Machwate M, Harada S, Leu CT, Seedor G, Labelle M, Gallant M, Hutchins S, Lachance N, Sawyer N, Slipetz D, Metters KM, Rodan SB, Young R, Rodan GA (2001) Prostaglandin receptor EP(4) mediates the bone anabolic effects of PGE(2). Mol Pharmacol 60:36-41. CrossRef Medline

Madisen L, Mao T, Koch H, Zhuo JM, Berenyi A, Fujisawa S, Hsu YW, Garcia AJ 3rd, Gu X, Zanella S, Kidney J, Gu H, Mao Y, Hooks BM, Boyden ES, Buzsáki G, Ramirez JM, Jones AR, Svoboda K, Han X, et al. (2012) A toolbox of Cre-dependent optogenetic transgenic mice for light-induced activation and silencing. Nat Neurosci 15:793-802. CrossRef Medline

Matsuura T, Takuwa H, Bakalova R, Obata T, Kanno I (2009) Effect of cyclooxygenase- 2 on the regulation of cerebral blood flow during neuronal activation in the rat. Neurosci Res 65:64-70. CrossRef Medline

Maubach KA, Davis RJ, Clark DE, Fenton G, Lockey PM, Clark KL, Oxford AW, Hagan RM, Routledge C, Coleman RA (2009) BGC20-1531, a novel, potent and selective prostanoid EP receptor antagonist: a putative new treatment for migraine headache. Br J Pharmacol 156:316-327. CrossRef Medline

Mazzetti S, Frigerio S, Gelati M, Salmaggi A, Vitellaro-Zuccarello L (2004) Lycopersicon esculentum lectin: an effective and versatile endothelial marker of normal and tumoral blood vessels in the central nervous system. Eur J Histochem 48:423-428. Medline

McCaslin AF, Chen BR, Radosevich AJ, Cauli B, Hillman EM (2011) In vivo 3D morphology of astrocyte-vasculature interactions in the somatosensory cortex: implications for neurovascular coupling. J Cereb Blood Flow Metab 31:795-806. CrossRef Medline

McCormick DA, Connors BW, Lighthall JW, Prince DA (1985) Comparative electrophysiology of pyramidal and sparsely spiny stellate neurons of the neocortex. J Neurophysiol 54:782-806. Medline

Mehl M, Bidmon HJ, Hilbig H, Zilles K, Dringen R, Ullrich V (1999) Prostacyclin synthase is localized in rat, bovine and human neuronal brain cells. Neurosci Lett 271:187-190. CrossRef Medline

Mishra A, O'Farrell FM, Reynell C, Hamilton NB, Hall CN, Attwell D (2014) Imaging pericytes and capillary diameter in brain slices and isolated retinae. Nat Protoc 9:323-336. CrossRef Medline

Mulligan SJ, MacVicar BA (2004) Calcium transients in astrocyte endfeet cause cerebrovascular constrictions. Nature 431:195-199. CrossRef Medline

Myren M, Baun M, Ploug KB, Jansen-Olesen I, Olesen J, Gupta S (2010) Functional and molecular characterization of prostaglandin E2 dilatory receptors in the rat craniovascular system in relevance to migraine. Cephalalgia 30:1110-1122. CrossRef Medline

Myren M, Olesen J, Gupta S (2011) Pharmacological and expression profile of the prostaglandin $\mathrm{I}(2)$ receptor in the rat craniovascular system. Vascul Pharmacol 55:50-58. CrossRef Medline

Nimmerjahn A, Kirchhoff F, Kerr JN, Helmchen F (2004) Sulforhodamine 101 as a specific marker of astroglia in the neocortex in vivo. Nat Methods 1:31-37. CrossRef Medline

Niwa K, Araki E, Morham SG, Ross ME, Iadecola C (2000) Cyclooxygenase-2 contributes to functional hyperemia in whisker-barrel cortex. J Neurosci 20:763-770. Medline

Niwa K, Haensel C, Ross ME, Iadecola C (2001) Cyclooxygenase-1 participates in selected vasodilator responses of the cerebral circulation. Circ Res 88:600-608. CrossRef Medline

Nizar K, Uhlirova H, Tian P, Saisan PA, Cheng Q, Reznichenko L, Weldy KL, Steed TC, Sridhar VB, MacDonald CL, Cui J, Gratiy SL, Sakadzić S, Boas
DA, Beka TI, Einevoll GT, Chen J, Masliah E, Dale AM, Silva GA, et al. (2013) In vivo stimulus-induced vasodilation occurs without IP3 receptor activation and may precede astrocytic calcium increase. J Neurosci 33:8411-8422. CrossRef Medline

Norup NA, Lauritzen M (2001) Coupling and uncoupling of activitydependent increases of neuronal activity and blood flow in rat somatosensory cortex. J Physiol 533:773-785. CrossRef Medline

Oda Y, Kodama S, Tsuchiya S, Inoue M, Miyakawa H (2014) Intracellular calcium elevation during plateau potentials mediated by extrasynaptic NMDA receptor activation in rat hippocampal CA1 pyramidal neurons is primarily due to calcium entry through voltage-gated calcium channels. Eur J Neurosci 39:1613-1623. CrossRef Medline

Olah ME, Jackson MF, Li H, Perez Y, Sun HS, Kiyonaka S, Mori Y, Tymianski M, MacDonald JF (2009) Ca2+-dependent induction of TRPM2 currents in hippocampal neurons. J Physiol 587:965-979. CrossRef Medline Pepicelli O, Fedele E, Berardi M, Raiteri M, Levi G, Greco A, Ajmone-Cat MA, Minghetti L (2005) Cyclo-oxygenase- 1 and -2 differently contribute to prostaglandin E2 synthesis and lipid peroxidation after in vivo activation of $N$-methyl-D-aspartate receptors in rat hippocampus. J Neurochem 93 1561-1567. CrossRef Medline

Porter JT, McCarthy KD (1996) Hippocampal astrocytes in situ respond to glutamate released from synaptic terminals. J Neurosci 16:5073-5081. Medline

Rancillac A, Rossier J, Guille M, Tong XK, Geoffroy H, Amatore C, Arbault S, Hamel E, Cauli B (2006) Glutamatergic control of microvascular tone by distinct GABA neurons in the cerebellum. J Neurosci 26:6997-7006. CrossRef Medline

Sang N, Zhang J, Marcheselli V, Bazan NG, Chen C (2005) Postsynaptically synthesized prostaglandin E2 (PGE2) modulates hippocampal synaptic transmission via a presynaptic PGE2 EP2 receptor. J Neurosci 25:9858 9870. CrossRef Medline

Schmidt R, Coste O, Geisslinger G (2005) LC-MS/MS-analysis of prostaglandin E2 and D2 in microdialysis samples of rats. J Chromatogr B Analyt Technol Biomed Life Sci 826:188-197. CrossRef Medline

Schmitz K, de Bruin N, Bishay P, Männich J, Häussler A, Altmann C, Ferreirós N, Lötsch J, Ultsch A, Parnham MJ, Geisslinger G, Tegeder I (2014) R-flurbiprofen attenuates experimental autoimmune encephalomyelitis in mice. EMBO Mol Med 6:1398-1422. CrossRef Medline

Scott NA, Murphy TH (2012) Hemodynamic responses evoked by neuronal stimulation via channelrhodopsin-2 can be independent of intracortical glutamatergic synaptic transmission. PLoS One 7:e29859. CrossRef Medline

Silva AC, Koretsky AP (2002) Laminar specificity of functional MRI onset times during somatosensory stimulation in rat. Proc Natl Acad Sci U S A 99:15182-15187. CrossRef Medline

Slanina KA, Schweitzer P (2005) Inhibition of cyclooxygenase-2 elicits a CB1-mediated decrease of excitatory transmission in rat CA1 hippocampus. Neuropharmacology 49:653-659. CrossRef Medline

Smith CJ, Zhang Y, Koboldt CM, Muhammad J, Zweifel BS, Shaffer A, Talley JJ, Masferrer JL, Seibert K, Isakson PC (1998) Pharmacological analysis of cyclooxygenase-1 in inflammation. Proc Natl Acad Sci U S A 95: 13313-13318. CrossRef Medline

Stark DT, Bazan NG (2011) Synaptic and extrasynaptic NMDA receptors differentially modulate neuronal cyclooxygenase-2 function, lipid peroxidation, and neuroprotection. J Neurosci 31:13710-13721. CrossRef Medline

Stefanovic B, Bosetti F, Silva AC (2006) Modulatory role of cyclooxygenase-2 in cerebrovascular coupling. Neuroimage 32:23-32. CrossRef Medline

Stichel CC, Müller CM, Zilles K (1991) Distribution of glial fibrillary acidic protein and vimentin immunoreactivity during rat visual cortex development. J Neurocytol 20:97-108. CrossRef Medline

Sun W, McConnell E, Pare JF, Xu Q, Chen M, Peng W, Lovatt D, Han X, Smith Y, Nedergaard M (2013) Glutamate-dependent neuroglial calcium signaling differs between young and adult brain. Science 339:197200. CrossRef Medline

Takano T, Tian GF, Peng W, Lou N, Libionka W, Han X, Nedergaard M (2006) Astrocyte-mediated control of cerebral blood flow. Nat Neurosci 9:260-267. CrossRef Medline

Tanaka S, Nakamura T, Sumitani K, Takahashi F, Konishi R, Itano T, Miyamoto O (2009) Stage- and region-specific cyclooxygenase expression and effects of a selective COX-1 inhibitor in the mouse amygdala kindling model. Neurosci Res 65:79-87. CrossRef Medline

Tang EH, Vanhoutte PM (2008) Gene expression changes of prostanoid synthases in endothelial cells and prostanoid receptors in vascular smooth 
muscle cells caused by aging and hypertension. Physiol Genomics 32: 409-418. CrossRef Medline

Thévenaz P, Ruttimann UE, Unser M (1998) A pyramid approach to subpixel registration based on intensity. IEEE Trans Image Process 7:27-41. CrossRef Medline

Tian P, Teng IC, May LD, Kurz R, Lu K, Scadeng M, Hillman EM, De Crespigny AJ, D’Arceuil HE, Mandeville JB, Marota JJ, Rosen BR, Liu TT, Boas DA, Buxton RB, Dale AM, Devor A (2010) Cortical depth-specific microvascular dilation underlies laminar differences in blood oxygenation level-dependent functional MRI signal. Proc Natl Acad Sci U S A 107:15246-15251. CrossRef Medline

Tocco G, Freire-Moar J, Schreiber SS, Sakhi SH, Aisen PS, Pasinetti GM (1997) Maturational regulation and regional induction of cyclooxygenase-2 in rat brain: implications for Alzheimer's disease. Exp Neurol 144:339-349. CrossRef Medline

Tsai PS, Kaufhold JP, Blinder P, Friedman B, Drew PJ, Karten HJ, Lyden PD, Kleinfeld D (2009) Correlations of neuronal and microvascular densities in murine cortex revealed by direct counting and colocalization of nuclei and vessels. J Neurosci 29:14553-14570. CrossRef Medline

Vazquez-Tello A, Fan L, Hou X, Joyal JS, Mancini JA, Quiniou C, Clyman RI, Gobeil F Jr, Varma DR, Chemtob S (2004) Intracellular-specific colocalization of prostaglandin E2 synthases and cyclooxygenases in the brain. Am J Physiol Regul Integr Comp Physiol 287:R1155-R1163. CrossRef Medline

Wang H, Hitron IM, Iadecola C, Pickel VM (2005) Synaptic and vascular associations of neurons containing cyclooxygenase- 2 and nitric oxide synthase in rat somatosensory cortex. Cereb Cortex 15:1250-1260. CrossRef Medline

Whiteus C, Freitas C, Grutzendler J (2014) Perturbed neural activity disrupts cerebral angiogenesis during a postnatal critical period. Nature 505: 407-411. CrossRef Medline

Wilhelmsson U, Bushong EA, Price DL, Smarr BL, Phung V, Terada M, Ellisman MH, Pekny M (2006) Redefining the concept of reactive astrocytes as cells that remain within their unique domains upon reaction to injury. Proc Natl Acad Sci U S A 103:17513-17518. CrossRef Medline
Woodward DF, Jones RL, Narumiya S (2011) International union of basic and clinical pharmacology: LXXXIII: classification of prostanoid receptors, updating 15 years of progress. Pharmacol Rev 63:471-538. CrossRef Medline

Woolsey TA, Rovainen CM, Cox SB, Henegar MH, Liang GE, Liu D, Moskalenko YE, Sui J, Wei L (1996) Neuronal units linked to microvascular modules in cerebral cortex: response elements for imaging the brain. Cereb Cortex 6:647-660. CrossRef Medline

Xie Y, Chen S, Anenberg E, Murphy TH (2013) Resistance of optogenetically evoked motor function to global ischemia and reperfusion in mouse in vivo. J Cereb Blood Flow Metab 33:1148-1152. CrossRef Medline

Yamagata K, Andreasson KI, Kaufmann WE, Barnes CA, Worley PF (1993) Expression of a mitogen-inducible cyclooxygenase in brain neurons: regulation by synaptic activity and glucocorticoids. Neuron 11:371-386. CrossRef Medline

Yang C, Kwan YW, Au AL, Poon CC, Zhang Q, Chan SW, Lee SM, Leung GP (2010) 14,15-Epoxyeicosatrienoic acid induces vasorelaxation through the prostaglandin $\mathrm{EP}(2)$ receptors in rat mesenteric artery. Prostaglandins Other Lipid Mediat 93:44-51. CrossRef Medline

Zeisel A, Muñoz-Manchado AB, Codeluppi S, Lönnerberg P, La Manno G, Juréus A, Marques S, Munguba H, He L, Betsholtz C, Rolny C, CasteloBranco G, Hjerling-Leffler J, Linnarsson S (2015) Cell types in the mouse cortex and hippocampus revealed by single-cell RNA-seq. Science 347:1138-1142. CrossRef Medline

Zhou M, Schools GP, Kimelberg HK (2006) Development of GLAST $(+)$ astrocytes and $\mathrm{NG2}(+)$ glia in rat hippocampus CA1: mature astrocytes are electrophysiologically passive. J Neurophysiol 95:134-143. CrossRef Medline

Zlokovic BV (2011) Neurovascular pathways to neurodegeneration in Alzheimer's disease and other disorders. Nat Rev Neurosci 12:723-738. CrossRef Medline

Zonta M, Angulo MC, Gobbo S, Rosengarten B, Hossmann KA, Pozzan T, Carmignoto G (2003) Neuron-to-astrocyte signaling is central to the dynamic control of brain microcirculation. Nat Neurosci 6:43-50. CrossRef Medline 